\title{
Lymphangiogenesis guidance by paracrine and pericellular factors
}

\author{
Kari Vaahtomeri, ${ }^{1}$ Sinem Karaman, ${ }^{1}$ Taija Mäkinen, ${ }^{2}$ and Kari Alitalo ${ }^{1}$ \\ ${ }^{1}$ Wihuri Research Institute, Translational Cancer Biology Program, Biomedicum Helsinki, University of Helsinki, FI-00014 \\ Helsinki, Finland; ${ }^{2}$ Department of Immunology, Genetics, and Pathology, Uppsala University, 75185 Uppsala, Sweden
}

Lymphatic vessels are important for tissue fluid homeostasis, lipid absorption, and immune cell trafficking and are involved in the pathogenesis of several human diseases. The mechanisms by which the lymphatic vasculature network is formed, remodeled, and adapted to physiological and pathological challenges are controlled by an intricate balance of growth factor and biomechanical cues. These transduce signals for the readjustment of gene expression and lymphatic endothelial migration, proliferation, and differentiation. In this review, we describe several of these cues and how they are integrated for the generation of functional lymphatic vessel networks.

Some of the most dense lymphatic networks are located under various epithelia that form the interface between the body and the outside environment; for example, in the skin and in the gut. In these locations, the immune cell trafficking functions of the lymphatics are of special importance; for instance, for the launching of adaptive immune responses against pathogens. The lymphatic system is also essential for the transport of interstitial fluid and associated solutes, metabolites, and macromolecules, which have extravasated from blood vessels. Blind-ended lymphatic capillaries form the portal of entry for interstitial fluid, antigen-presenting cells, and lymphocytes (Aebischer et al. 2014; Aspelund et al. 2016; Betterman and Harvey 2016). From the capillary network, the interstitial fluid-now called lymph-flows via precollector and collector vessels and through a series of lymph nodes back into the systemic circulation via the thoracic duct, leading to entry of substances transported in lymph into the bloodstream (Schulte-Merker et al. 2011; Koltowska et al. 2013). The lymphatic network is a low-pressure system, where lymph is propelled forward by the squeezing action of smooth muscle cells (SMCs) that surround the lymphangions between valves of the collecting vessels and by vasomotion and breathing that promote suction

[Keywords: lymphangiogenesis; VEGF-C; VEGFR3; lymphatic vessel sprouting; interstitial fluid pressure; lymphedema; lymphatic vessel basement membrane]

Corresponding author: kari.alitalo@helsinki.fi

Article is online at http://www.genesdev.org/cgi/doi/10.1101/gad.303776. 117. in the downstream collector vessels (Bazigou and Makinen 2013).

With the exception of the Schlemm's canal in the eyes, meningeal lymphatic vessels, and the majority of the (lacteal) lymphatic vessels in the intestine, most lymphatic networks are generated during embryonic development (Kim et al. 2007; Aspelund et al. 2014, 2015; Kizhatil et al. 2014; Nurmi et al. 2015). However, they also undergo dynamic changes in adults. Lymphatic vessels can grow in length and caliber (lymphangiogenesis) in various pathological conditions, such as inflammation, wound healing, tumorigenesis, and in association with tissue transplantation. A common feature in many of these conditions is tissue edema and inflammation, which increase the demand for fluid drainage and immune cell trafficking. When the lymphatic network undergoes remodeling, the enlarged vessels with their increased tissue drainage capacity may benefit the resolution of inflammation by enabling enhanced removal of accumulated tissue fluid, immune cells, tissue debris, chemokines, growth factors, etc. (Aebischer et al. 2014; Betterman and Harvey 2016). Increased lymphatic function can sometimes also lead to adverse effects. For example, lymphangiogenesis can increase the severity of transplant rejection (Dashkevich et al. 2016). In cancer, it can facilitate the spread of tumor cells to the lymph nodes and from there to the systemic circulation, with subsequent metastatic colonization of distant organs (Alitalo 2011; Stacker et al. 2014). As these examples indicate, development of molecular tools to control lymphangiogenesis would be beneficial for the treatment of several diseases.

The stepwise process of lymphangiogenesis has similarities to the better-studied blood vascular angiogenesis and the growth of the gas-transporting tracheal system in Drosophila melanogaster (Ochoa-Espinosa and Affolter 2012). Lymphangiogenic growth starts upon exposure of lymphatic endothelial cells (LECs) to growth factors or biomechanical stimuli, which in many cases leads to activation of vascular endothelial growth factor (VEGF)

(C) 2017 Vaahtomeri et al. This article is distributed exclusively by Cold Spring Harbor Laboratory Press for the first six months after the full-issue publication date (see http://genesdev.cshlp.org/site/misc/terms.xhtml). After six months, it is available under a Creative Commons License (Attribution-NonCommercial 4.0 International), as described at http:// creativecommons.org/licenses/by-nc/4.0/. 
receptor 3 (VEGFR3) (Fig. 1). Available data support the view that, in lymphangiogenesis, as in angiogenesis, the growing lymphatic vessels are guided by migrating tip cells, which display filopodia and cellular protrusions that sample the pericellular environment in search of guidance cues (Figs. 1, 2; Gerhardt et al. 2003; Zheng et al. 2011). The tip cell guides the forming branch, and endothelial proliferation behind the tip cell allows the elongation of the branch (Gerhardt et al. 2003; Baluk et al. 2005). The growth of new branches ceases upon decreased growth factor exposure, or, in some cases, growth is stalled by an increase of inhibitory signals, such as IFN- $\gamma$, TGF- $\beta$, endostatin, neostatin-7, or thrombospondin, which act directly on LECs or via control over growth factor production by other cell types (Fig. 1; Brideau et al. 2007; Clavin et al. 2008; Kojima et al. 2008; Oka et al. 2008; Avraham et al. 2010; Cursiefen et al. 2011; Kataru et al. 2011; Ou et al. 2011; Zampell et al. 2012). After some pruning of the newly formed branches, some of them are stabilized to form capillaries or collector vessels. The maturation of collectors involves the development of valves and SMC investment (Bazigou and Makinen 2013; Martinez-Corral and Makinen 2013). The intercellular cadherin junctions of the capillaries un- dergo a switch from a zipper-like structure to button-like connections (Yao et al. 2012), and this is accompanied by the formation of anchoring filaments that connect the LECs to the pericellular matrix (Leak and Burke 1968). Interestingly, during embryonic growth, the LEC junctions are zippers and change to buttons slowly around birth but revert back to zippers upon stimulation by growth factor or inflammatory processes (Yao et al. 2012).

In this review, we first outline the main principles of the formation of lymphatic vessel networks during development and their expansion in pathological conditions such as inflammation and tumorigenesis. We then describe the mechanisms of lymphangiogenesis; i.e., how VEGF-C activates its cognate receptor, VEGFR3, in LECs, leading to sprouting lymphangiogenesis. We next discuss the modulation of VEGFR3 activity by its coreceptors. We also describe how mechanical cues, such as tissue fluid pressure and tissue structures such as arteries and extracellular matrix (ECM), contribute to lymphangiogenesis guidance. Finally, we describe some of the wellestablished mouse models for lymphangiogenesis (Fig. 2). Throughout the review, we focus on the guidance mechanisms of lymphangiogenesis in comparison with angiogenesis in mammals and zebrafish.

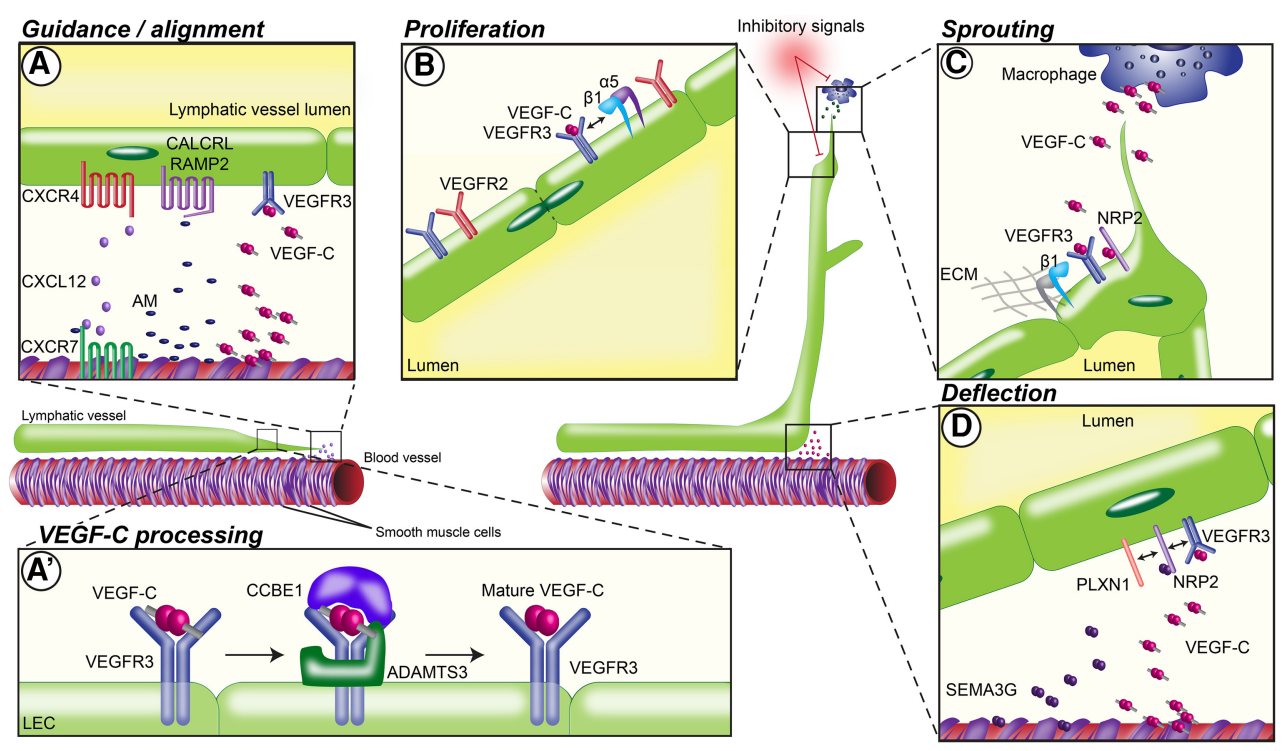

Figure 1. Pericellular cues that guide lymphatic vessel growth. $\left(A, A^{\prime}\right)$ Arterial endothelial cells and SMCs secrete lymphangiogenic guidance cues that contribute to the alignment of large lymphatic collectors with arteries. VEGF-C binds to pericellular matrix and LEC surface proteins, such as VEGFR3, neuropilin 2 (NRP2), and syndecan-4, and is processed upon its interaction with extracellular matrix (ECM) adapter, collagen- and calcium-binding EGF domain-containing protein 1 (CCBE1), and the ADAMTS3 protease as shown in $A^{\prime}$. In zebrafish and mice, CXCL12 produced by blood vascular endothelial cells guides lymphatic growth via binding to its receptor, CXCR4, on LECs. Adrenomedullin (AM) binds to the RAMP2 and CALCRL receptors in mice. The chemokine sink CXCR7 regulates these interactions by sequestering both CXCL12 and adrenomedullin. (B) Upon growth factor-induced activation, both VEGFR3 and VEGFR2 can stimulate LEC proliferation, and VEGFR3 interaction with $\beta 1$ integrins, such as $\alpha 5 \beta 1$, enhances the lymphangiogenic signals. (C) The sprouting and branching of lymphatic vessels is dependent on VEGF-C signaling via the VEGFR3-NRP2 receptor complex. Integrin a5 $\beta 1$ ligands fibronectin and collagen in the ECM increase VEGFR3 phosphorylation in the absence of a VEGFR3 ligand; they also potentiate VEGF-C-induced VEGFR3 activation and LEC migration. Macrophages provide a major source of VEGF-C in lymphangiogenesis associated with inflammation. The growth-promoting factors are counteracted by inhibitory signals, such as TGF- $\beta$ and INF- $\gamma$, which act directly on LECs or affect VEGF-C production by, e.g., macrophages (see the overview figure). (D) The deflection of lymphatic vessel sprouts away from arteries has been suggested to be driven by arterial expression of semaphorin 3G (SEMA3G), which induces LEC repulsion via a plexin 1 (PLXN1)-NRP2-VEGFR3 receptor complex. 


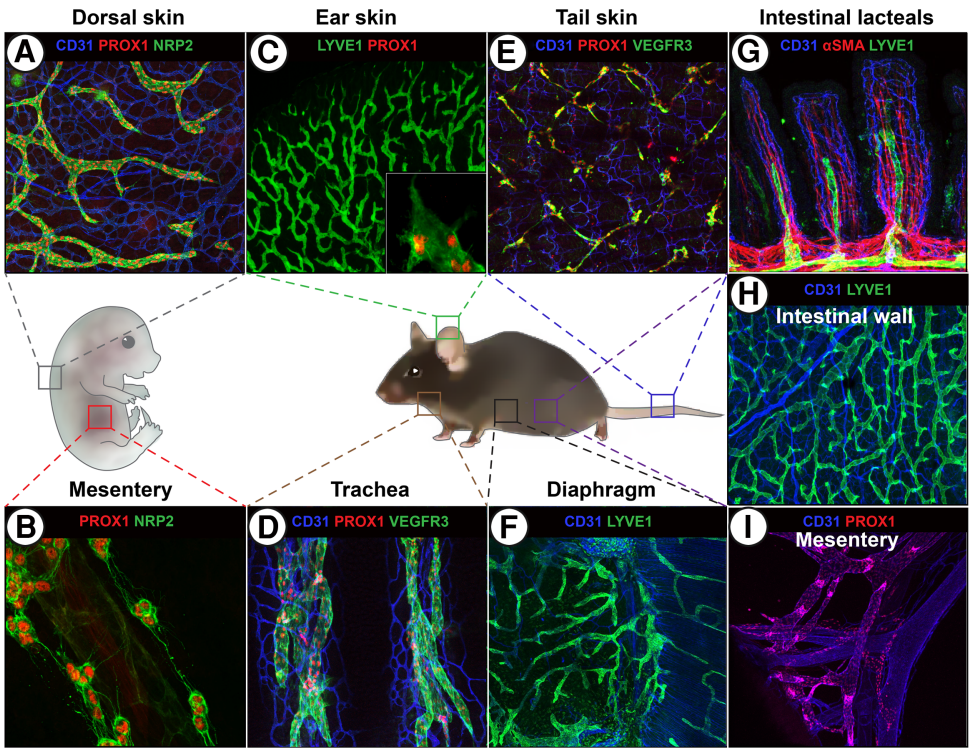

Figure 2. Examples of ongoing lymphangiogenesis in mouse embryos and postnatal mice. (A) Embryonic skin dermis at embryonic day 14 (E14) stained for CD31 (blue), PROX1 (red), and NRP2 (green). (B) LEC clusters in the process of assembling to form mesenteric lymphatic vessels at E14, here stained for PROX1 (red) and NRP2 (green). (C) LYVE1 (green) staining of developing lymphatic vessels in the ventral part of the ear at postnatal day 16 (P16). The inset shows one of the growing lymphatic vessel tips, with the LEC nuclei indicated using PROX1 (red). (D,E) CD31 (blue), PROX1 (red), and VEGFR3 (green) whole-mount staining of the trachea $(D)$ and tail dermis $(E)$ at P5. (F) CD31 (blue) and LYVE1 (green) staining of the pleural side of a P5 diaphragm. $(G, H)$ CD31 (blue), a-smooth muscle actin (aSMA; red), and LYVE1 (green) staining of (lacteal) lymphatic vessels in intestinal villi $(G)$ and the intestinal wall $(H)$ in adult mice. (I) CD31-stained (blue) and PROX1-stained (red) mesenteric lymphatic vessels at $\mathrm{P} 7$.

\section{Lymphangiogenesis in development}

Most of the lymphatic vessels in mice and zebrafish arise from LECs sprouting from embryonic veins (Sabin 1902; Wigle and Oliver 1999; Isogai et al. 2003; Yaniv et al. 2006; Srinivasan et al. 2007). In zebrafish, phagocytic perivascular cell populations resembling LECs have been found recently in the brain that do not form vessels but are required for the formation of the cerebral blood vessels (Bower et al. 2017a; van Lessen et al. 2017; Venero Galanternik et al. 2017). An interesting case of lymphatic vessel specialization in fish is their involvement in fin erection and thus locomotion in tunas (Pavlov et al. 2017). In mouse embryos, the first committed LEC progenitors appear in the cardinal vein at embryonic day 9.5 (E9.5). These cells express SOX18 (a SRY-related HMG-box transcription factor) and differ from the majority of other venous cells by expression of homeobox transcription factor PROX1 and LYVE1 (Wigle and Oliver 1999; Schacht et al. 2003; Francois et al. 2008; Hagerling et al. 2013). SOX18 induces expression of the downstream Prox1, which is essential for LEC specification and the subsequent formation of lymphatic vessel networks (Wigle and Oliver 1999; Francois et al. 2008; Johnson et al. 2008). PROX1 drives lymphatic identity and its maintenance by directly inducing expression of LEC-specific genes and suppressing blood endothelial cell (BEC)-specific genes in collaboration with its binding partners, such as the nuclear receptor COUP-TFII (Petrova et al. 2002; Wigle et al. 2002; Lin et al. 2010; Srinivasan et al. 2010).

Based on live imaging of zebrafish embryos, the initial LEC specification takes place on the ventral side of the cardinal vein, where Wnt5b, secreted by the neighboring endoderm, induces the specification of LEC lineage cells (Nicenboim et al. 2015). These cells subsequently migrate to the dorsal side of the cardinal vein. It has been suggested that on the dorsal side, the committed LECs arise via asymmetric fate determination following cell division; the daughter cells expressing increased levels of Proxl then become destined to the lymphatic lineage (Koltowska et al. 2015). Also in mouse embryos, PROX1-positive LEC progenitors are spatially restricted to the dorsal side of the cardinal vein at E10.5 (Wigle and Oliver 1999). WNT activation can increase Prox1 expression via transcription factor 4 (TCF4)-binding sites upstream of the Prox1 gene in lymphatic endothelial, neuronal, and tumor cells (Petrova et al. 2008; Karalay et al. 2011; Cha et al. 2016). However, $\beta$-catenin deletion in mouse embryos from E9.5 onward did not interfere with LEC differentiation. Rather, $\beta$-catenin was necessary for lymphatic vasculature morphogenesis and valve formation, possibly via shear stress sensing and regulation of FOXC2 expression (Cha et al. 2016).

After delamination, the PROX1-positive LECs migrate dorsally as strings of loosely connected spindle-shaped cells and, at E11.5, form the first lumenized lymphatic structures ("lymph sacs"), the peripheral longitudinal lymphatic vessel (PLLV), and the primordial thoracic duct (pTD) (Yang et al. 2012; Hagerling et al. 2013). It has been suggested that instead of LEC proliferation, abundant LEC delamination from the cardinal vein and possibly from the superficial blood vessel plexus comprises the major source of migrating LECs (Hagerling et al. 2013). Formation of additional lymph sacs takes place in other anatomical locations at later developmental time points. For example, the PROX1-positive LECs in the superior mesenteric vein are specified at E12.5 and form the mesenteric lymph sac by E14 (Kim et al. 2007; Stanczuk et al. 2015). Lymph sacs will subsequently give rise to most of the primitive lymphatic vessel plexuses in embryos via vigorous LEC sprouting and proliferation (Hagerling et al. 2013). Thereafter, additional pruning and further sprouting sculpt the final lymphatic vessel network, consisting of lymphatic capillaries, precollectors, collectors, and lymph nodes organized in a hierarchical manner. The lymphatic network patterns in various tissues differ 
greatly from each other, reflecting the physical constraints and functional demands imposed by the host tissue (Ulvmar and Makinen 2016).

Although most of the lymphatic vascular plexuses originate from Prox1-positive venous endothelia (Srinivasan et al. 2007), recent reports have indicated a contribution by nonvenous sources in diverse tissues (for review, see Ulvmar and Makinen 2016). Mesenteric lymphatic vessels are formed from isolated clusters of LECs (Fig. 2B), whose origin was traced to progenitors derived from blood-forming hemogenic endothelium (Stanczuk et al. 2015). In the lumbar dermis and heart, some of the LECs were negative for Tie2-Cre lineage tracing, suggesting that these cells had a nonendothelial origin (Klotz et al. 2015; MartinezCorral et al. 2015). According to Klotz et al. (2015), these LECs are similar to cells in a VAV1-positive hematopoietic cell lineage in the heart. The precise contribution of alternative LEC sources and their importance for the formation of different lymphatic vascular beds are still unclear. It is not understood why certain lymphatic networks are composed of LECs derived from various sources. It is possible that LECs from diverse backgrounds could have differential functions within the mature network or ensure efficient and rapid (re)vascularization. These findings also call for studies on the contribution of lymphvasculogenesis in pathological conditions.

\section{Lymphangiogenesis in pathological conditions}

In adults, lymphangiogenesis is reactivated in inflammation, wound healing, and tumorigenesis. Although lymphangiogenesis in adults operates with the same principles as in embryos, it is less well coordinated by the appropriate signals in pathological processes, and thus lymphatic vessels often become malformed and poorly functional. Lymphatic vessel density increases locally at sites of inflammation in tissues and in their downstream lymph nodes, which receive lymphangiogenic signals from the inflamed site (for review, see Aebischer et al. 2014; Kim et al. 2014). Substantial lymphatic vasculature is required for the resolution of inflammation and efficient tissue clearance. Increased lymphatic vessel density in transgenic animals overexpressing VEGF-C improves the resolution of tissue edema in models of cutaneous contact hypersensitivity, UV irradiation, or lipopolysaccharidemediated inflammation (Kataru et al. 2009; Huggenberger et al. 2011). On the other hand, inhibition of lymphangiogenesis prolongs the resolution of tissue edema in acute inflammation of the mouse ear or peritoneum and in TNFa-induced arthritis (Guo et al. 2009; Kataru et al. 2009; Kim et al. 2009). However, blocking lymphangiogenic signals can alleviate rejection of transplanted cardiac, corneal, and pancreatic tissue allografts by preventing antigen presentation in the draining lymph nodes /Chen et al. 2004; Zhang et al. 2009; Dietrich et al. 2010; Nykanen et al. 2010; Dashkevich et al. 2016).

Inflammation-associated lymphangiogenesis is induced by inflammatory cytokines such as TNFa and IL-1 (which stimulate target cells), and leukocytes (e.g., macrophages) can produce substantial amounts of VEGF-C (Enholm et al. 1997; Matsui et al. 2003; Kataru et al. 2009; Kim et al. 2009). Macrophages and other bone marrow-derived cells have also been reported to intercalate in between the LECs at a very low rate during the formation of lymphatic vessels and, in some cases, have been detected to express the LEC markers LYVE1 and PROX1 (Maruyama et al. 2005; Religa et al. 2005; Jiang et al. 2008; Zumsteg et al. 2009; Lee et al. 2010; Hall et al. 2012; Hirai et al. 2013). However, there is no lineage tracing evidence that these cells would directly contribute to expansion of lymphatic vessels in inflammation.

The stability of inflammation-induced lymphatic neovessels varies between tissues. In the cornea, lymphatic capillaries induced by a surgical suture started to regress immediately upon suture removal, but, 6 mo later, short fragments still persisted (Cursiefen et al. 2006). It was suggested that they can act as seeds of accelerated lymphangiogenesis in recurring inflammation (Kelley et al. 2013). Furthermore, in the trachea, entire lymphatic vessel networks generated during inflammation persisted for long time periods after the resolution of inflammation (Baluk et al. 2005), whereas in lymph nodes treated with a single injection of lipopolysaccharide, the lymphatic capillary area peaked $3 \mathrm{~d}$ later and returned to normal in $2 \mathrm{wk}$ (Kataru et al. 2011). The reasons for such variation in lymphatic vessel regression are not known (for review, see Kim et al. 2014).

Increased expression of lymphangiogenic factors occurs also in a variety of tumors that promote lymphangiogenesis in the peritumoral area and enlarge the downstream collecting lymphatic vessels as well as the subcapsular sinus network of the draining lymph nodes (for review, see Alitalo 2011; Karaman and Detmar 2014; Stacker et al. 2014). Lymphatic vessels can also grow intratumorally (Beasley et al. 2002; Dadras et al. 2003). Intratumoral vessels either have penetrated the tumor or represent pre-existing lymphatics trapped by the growing tumor (Stacker et al. 2014). VEGF-C produced by tumor cells and by inflammatory cells in the tumor stroma promotes lymphangiogenesis (Salven et al. 1998; Achen et al. 2001; Karpanen et al. 2001; Schoppmann et al. 2002), which facilitates the dissemination of tumor cells into the lymphatic vessels and lymph nodes (Karpanen et al. 2001; Mandriota et al. 2001; Skobe et al. 2001; Stacker et al. 2001).

It has been suggested that lymphatic and lymph node colonization facilitates tumor cell entry into the systemic circulation (Karpanen and Alitalo 2001). Indeed, tumor-induced lymphangiogenesis is associated with increased lymph node metastasis and worse disease-free/overall survival of patients, and surgical removal of cancer cell-harboring lymph nodes can improve patient survival (Moertel et al. 1995; Dadras et al. 2003, 2005; Nakamura et al. 2005; Renyi-Vamos et al. 2005; Saad et al. 2006; Takanami 2006; Tobler and Detmar 2006; Adachi et al. 2007; Kaneko et al. 2007; Matsumoto et al. 2007; Doekhie et al. 2008; Mumprecht and Detmar 2013). However, metastases can also occur via an exclusive hematogenous route. Reconstruction of phylogenetic trees of primary tumors and associated metastases from colon cancer 
patients showed that $35 \%$ of liver and lymph node metastases had the same subclonal origin in the primary tumor, reflecting either the metastatic route or the capability of a metastatic tumor clone to efficiently spread to several independent locations (Naxerova et al. 2017). In mouse models, lymphangiogenic factors produced by tumor cells facilitate lymph node metastases, and blocking of lymphangiogenesis in various tumor models attenuates tumor dissemination (Karpanen et al. 2001; Mandriota et al. 2001; Skobe et al. 2001; Stacker et al. 2001; He et al. 2002, 2005; Krishnan et al. 2003; Lin et al. 2005; Roberts et al. 2006). However, increased marginal lymphatic vessels and a high "immunoscore" (i.e., density of tumor-infiltrating cytotoxic $\mathrm{CD}^{+}$and memory $\mathrm{CD}_{45 \mathrm{RO}^{+}}$ $\mathrm{T}$ cells) in human colorectal carcinoma are associated with protection against the generation of distant metastases (Galon et al. 2006; Kirilovsky et al. 2016; Mlecnik et al. 2016). In melanoma, VEGF-C levels correlated with tumor infiltration of naïve $\mathrm{T}$ cells and enhanced response to immunotherapy (Fankhauser et al. 2017). Thus, lymphatic vessels likely have a dual role during tumor progression, allowing metastatic escape but also regulating the immune recognition and critical checkpoints in anti-tumor responses.

\section{VEGF-C and other lymphangiogenic growth factors}

VEGF-C is so far the only specific growth factor that is essential for embryonic lymphangiogenesis (Karkkainen et al. 2004). In the absence of VEGF-C, PROX1-positive endothelial cells are specified in the cardinal vein of developing mouse embryos but fail to delaminate, which leads to failure of primary lymph sac and lymphatic network formation and prenatal death (Karkkainen et al. 2004; Hagerling et al. 2013). Heterozygous embryos survive but develop hypoplastic lymphatic vessels (Karkkainen et al. 2004). Conditional deletion of $V e g f c$ at a later developmental time point leads to absence of, e.g., lacteals in the intestine and hypoplastic Schlemm's canal in the eyes (Aspelund et al. 2014; Nurmi et al. 2015). Furthermore, VEGF-C/D sequestration by epidermally expressed soluble VEGFR3Ig protein (VEGF-C/D trap) inhibits cutaneous and meningeal lymphatic vessel development (Makinen et al. 2001; Haiko et al. 2008; Aspelund et al. 2015).

VEGF-C is also indispensable for lymphangiogenesis in adult tissues, as shown in models of acute inflammation in which an inflammatory response was induced in the trachea by Mycoplasma pulmonis, in the peritoneum by lipopolysaccharide, or in the ear dermis by lipopolysaccharide or lipoteichoic acid and muramyl dipeptide (Baluk et al. 2005; Kataru et al. 2009; Kim et al. 2009). In these models, lymphangiogenesis was prevented by the VEGF-C/D trap. Interestingly, the maintenance of lymphatic capillaries seems to be dependent on constant VEGF-C signaling in some tissues. Deletion of $V e g f c$ in adult mice caused slow degeneration of intestinal lacteals, whereas the maintenance of dermal lymphatic vessels was independent of a constant supply of VEGF-C (Aspelund et al. 2014; Nurmi et al. 2015). Furthermore, in contrast to dermal LECs, it was reported that the lacteal LECs proliferate at a slow rate, and some of the lacteal tips display a tip cell phenotype even in adult mice (Bernier-Latmani et al. 2015).

Although VEGF-C and perhaps Wnt5a (see above; Nicenboim et al. 2015) are the only indispensable growth factors for lymphangiogenesis, several other growth factors can also induce lymphatic growth. For instance, the VEGF-C-related VEGF-D induces lymphangiogenesis when overexpressed (Stacker et al. 2001), and its deletion results in mild lymphatic vessel hypoplasia in the lungs and slightly decreased lymphatic vessel caliber in the dermis (Baldwin et al. 2005; Paquet-Fifield et al. 2013). In zebrafish, VEGF-D is indispensable for facial lymphangiogenesis (Astin et al. 2014; Bower et al. 2017b). Ectopic expression of FGF2 can also induce lymphangiogenesis, and Fgfr1 and Fgfr3 double-mutant mice show reduced growth of dermal lymphatic vessels at E15.5 (Kubo et al. 2002; Cao et al. 2004b; Chang et al. 2004; Yu et al. 2017). Ectopic expression of several other growth factors, such as VEGF (Nagy et al. 2002; Cao et al. 2004b; Cursiefen et al. 2004; Kunstfeld et al. 2004), angiopoietin 1 (Gale et al. 2002; Morisada et al. 2005; Tammela et al. 2005), angiopoietin 2 (Gale et al. 2002), PDGF-BB (Cao et al. 2004a), EGF (Marino et al. 2013), IGF-1 (Bjorndahl et al. 2005), and HGF (Kajiya et al. 2005; Cao et al. 2006; Gibot et al. 2016), can induce lymphangiogenesis in mouse tissues. At least FGF2-, angiopoietin 1-, and HGF-induced lymphangiogenesis is inhibited by the VEGF-C/D trap (Kubo et al. 2002; Chang et al. 2004; Tammela et al. 2005; Cao et al. 2006). Thus, in addition to direct effects on LECs, these growth factors may act by recruiting leukocytes, which can produce VEGF-C/D (for review, see Zumsteg and Christofori 2012). Another possibility is that they induce VEGF-C expression in blood vascular endothelium or associated SMCs, which leads to lymphangiogenesis via angiocrine mechanisms (Kubo et al. 2002; Cao et al. 2006).

\section{Sources of VEGF-C}

When overexpressed, VEGF-C provides directional cues for LEC migration and lymphatic vessel extension. For example, LECs delaminating from the jugular vein migrate toward the paracrine VEGF-C source (Karkkainen et al. 2004). VEGF-C induces directed LEC migration in vitro (Joukov et al. 1996), and beads soaked in recombinant VEGF-C were capable of recruiting LECs in Vegfc-deleted embryos (Karkkainen et al. 2004). Lymphatic vessels also grow toward VEGF-C-expressing tumors and encircle the tumor foci, occasionally penetrating into the tumor stroma (Stacker et al. 2014). A point source of VEGF-C may form a LEC-guiding gradient, or the tip LEC may follow a source of VEGF-C that advances ahead of the growing lymphatic capillary tip. Furthermore, extracellular processing of VEGF-C by the ADAMTS3 metallprotease and associated collagen- and calcium-binding EGF domain-containing protein 1 (CCBE1) may shape active VEGF-C gradients (see below). Such mechanisms are known from other model systems. For example, angiogenesis toward the midline in the hindbrain is regulated by a 
VEGF gradient and neuropilin binding (Ruhrberg et al. 2002), and tracheal vessel growth in Drosophila is directed by a gradient formed by a point source of FGF (Sutherland et al. 1996). In the developing retina, the angiogenic vessel front (the leading edge) follows the advancing border of hypoxic tissue, which shows high VEGF expression by the underlying astrocytes (Stone et al. 1995; Gerhardt et al. 2003). So far, it has been difficult to explore such mechanisms in the case of VEGF-C because of the lack of specific reagents for the localization of the activated form of VEGF-C.

Macrophages are often detected in the vicinity of forming lymphatic vessels in embryos and in inflamed and tumor tissues in adults (Kelley et al. 2013; Lee et al. 2014; Ochsenbein et al. 2016). However, claims that macrophages incorporate to lymphatic vessels and transdifferentiate into proliferating LECs have not been supported by hematopoietic lineage tracing using Vav-Cre or Csf1r-iCre mice (Maruyama et al. 2005; Religa et al. 2005; Kerjaschki et al. 2006; Bertozzi et al. 2010; Gordon et al. 2010; MartinezCorral et al. 2015). However, macrophages are essential for lymphangiogenesis associated with inflammation. They are known to produce angiogenic cytokines, including VEGF-C and VEGF-D (Fig. 1C; Schoppmann et al. 2002). Clodronate liposomes, which have been used to deplete macrophages systemically, inhibited lymphangiogenesis induced by lipopolysaccharide in the ear, skin, and diaphragm; by corneal suture in the eye; and by a high-salt diet in the skin (Maruyama et al. 2005; Kataru et al. 2009; Kim et al. 2009; Machnik et al. 2009).

Although macrophages stimulate LEC proliferation in vitro (Gordon et al. 2010), the role of macrophages in developmental lymphangiogenesis is less obvious. op/op mice, which lack macrophage colony-stimulating factor (M-CSF and CSF-1)-dependent macrophages, show delayed development of dermal and tracheal lymphatic vessels (Kubota et al. 2009). Lymphangiogenesis induced by ischemia and tumors was also attenuated in the op/op mice (Kubota et al. 2009). Furthermore, defective CCL2CCR2 chemokine signaling led to decreased association of macrophages with the lymphatic vessels and decreased density of the dermal lymphatic network, possibly by reducing the concentration of VEGF-C/D that interacts with its receptor on the LECs (Lee et al. 2014). Interesting$1 y$, depletion of the PU.1 transcription factor or M-CSF-dependent macrophages in the corresponding gene targeted mice led to LEC hyperproliferation and lymphatic vessel dilation. Although it was suggested that PU.1- and Csf1r-dependent cells inhibit lymphangiogenesis, VEGFC/D expression was increased in PU.1 embryos, suggesting alternative overcompensating mechanisms (Gordon et al. 2010).

Immunohistochemistry for VEGF-C shows staining in the endothelium and arterial SMCs in adult mice, reflecting its binding to the vascular endothelial cell surfaces and production by SMCs and possibly BECs (Skobe et al. 1999; Partanen et al. 2000; Tammela et al. 2008). $\beta$-Galactosidase staining of tissues from heterozygous $V e g f c^{w t / l a c Z}$ mice confirmed Vegfc expression in SMCs in E10.5 embryos and intestinal arteries in adults (Karkkainen et al.
2004; Nurmi et al. 2015). Furthermore, the circular smooth muscle fibers of the intestinal wall and elongated SMCs extending into the gut villi were positive for $\beta$-galactosidase (Nurmi et al. 2015). VEGF-C production by SMCs could explain why the intestinal lacteals run parallel to the intestinal SMC fibers and why lymphatic vessels accompany major arteries, although the CXCL12/CXCR4 chemokine signaling system is also involved (see below; Fig. 1A; Cha et al. 2012). However, the proof of SMC-produced VEGF-C function would require targeted deletion of VEGF-C in these cells. Overall, cell- and tissue-specific patterns of VEGF-C expression and physical constraints for the growth of lymphatic vessels may explain the tissue-specific patterns of many lymphatic networks.

\section{VEGF-C activation}

Unlike other members of the VEGF family, VEGF-C and VEGF-D are produced as precursor proteins, which require processing of their C-terminal and $\mathrm{N}$-terminal propeptides to achieve full activity toward their cognate receptors, VEGFR3 and VEGFR2 (Joukov et al. 1997). Concomitant with its secretion, the VEGF-C precursor undergoes C-terminal cleavage by proprotein convertases (Siegfried et al. 2003). The resulting VEGF-C form is poorly active, but subsequent $\mathrm{N}$-terminal processing greatly potentiates its receptor binding. Recent studies have revealed that the processing of the $\mathrm{N}$ terminus is a complex mechanism, requiring the scaffold protein CCBE1 (Jeltsch et al. 2014; Le Guen et al. 2014; Jha et al. 2017). Both CCBE1 and the ADAMTS3 metalloproteinase are essential for cleavage of VEGF-C into its active form in vivo and in vitro (Jeltsch et al. 2014; Janssen et al. 2016). Importantly, CCBE1-inactivating mutations in the collagen domain, calcium-binding EGF domain, or cysteine-rich domain upstream of the EGF domain have been found in patients with Hennekam syndrome, which involves severe lymphedema (Alders et al. 2009, 2013; Connell et al. 2010). Furthermore, homozygous Ccbe1 mutations prevent the formation of all primitive lymphatic structures in mice and zebrafish (Hogan et al. 2009; Bos et al. 2011). In Ccbe1 mutant mice, LECs are specified and able to delaminate from the cardinal vein in small amounts but fail to migrate and form PLLV and pTD (Hagerling et al. 2013). The fact that LECs still delaminate in Ccbe1 mutants, but not in Vegfc mutants, suggests that the unprocessed VEGF-C also has some activity toward VEGFR3. Alternatively, low levels of VEGF-C cleavage may occur in the absence of CCBE1. In line with the developmental phenotype, conditional deletion of Ccbe 1 in adult mice abolishes lymphangiogenesis induced by VEGF-C overexpression (Bui et al. 2016). Moreover, CCBE1 overexpression in adult mice synergizes with VEGF-C expression for improved lymphangiogenesis (Jeltsch et al. 2014). The ADAMTS3 protease that activates VEGF-C was previously considered to be of major importance for the processing of interstitial procollagens to collagen (for review, see Fernandes et al. 2001). It was therefore surprising that the Adamts3-deleted mice had no connective tissue phenotype but instead lacked 
lymphatic vessels and had severe tissue swelling as embryos, resulting in prenatal death (Janssen et al. 2016).

Mechanistically, CCBE1 could present a scaffold that directly binds ADAMTS3, and complex formation may be required for the binding of pro-VEGF-C in vitro (Jeltsch et al. 2014; Bui et al. 2016). The $\mathrm{N}$ terminus of CCBE1 interacts also with VEGFR3 and the pericellular matrix components vitronectin and collagens I, IV, and V (Bos et al. 2011; Jeltsch et al. 2014). Immature VEGF-C also binds VEGFR3 and cell surface/ECM heparan sulfates in vitro (Yin et al. 2011; Jeltsch et al. 2014; Johns et al. 2016). Most VEGF-C activation may thus occur on the endothelial cell surface or in the pericellular matrix. It is also interesting that the C-terminal propeptide contains a repetitive arrangement of cysteine residues, which is otherwise exclusively known from the salivary proteins of silk-weaving mosquito larvae of the genus Chironomus, which can form fibrous structures (Joukov et al. 1996; Jha et al. 2017). Whether latent VEGF-C is present in fibrillar silk-like matrix structures in mammalian tissues is not known yet, but it is clear that spatiotemporal regulation of VEGF-C activity may be achieved by either regulated VEGF-C production or three-dimensional (3D) integration of the components of its activation machinery. Furthermore, differences in ECM composition or VEGFR3 protein levels likely create hot spots for VEGF-C activation and localized/guided lymphangiogenesis.

\section{The VEGF-C-VEGFR3 signaling complex in lymphangiogenesis}

Several lines of evidence support the key role of VEGFR3 in lymphangiogenesis (Fig. 1). Processed "mature" VEGF$\mathrm{C}$ binds to and activates its primary receptor, VEGFR3; the main angiogenic receptor VEGFR2; and, to some extent, their heterodimers (Joukov et al. 1996; Dixelius et al. 2003). In humans and mice, heterozygous VEGFR3 and VEGFC mutations lead to lymphedema (lymphedema type 1A and 1D, Chy mice) (Irrthum et al. 2000; Karkkainen et al. 2000, 2001; Gordon et al. 2013; Brouillard et al. 2014). Furthermore, combined Vegfc and Vegfr3 heterozygosity leads to embryonic lethality, and expression of the VEGF-C/D trap in the developing epidermis prevents lymphatic vessel development in the skin (Makinen et al. 2001; Haiko et al. 2008). VEGFR3 is also expressed in developing blood vessels and in fenestrated endothelia and the tip cells of angiogenic vessel sprouts in adults (Valtola et al. 1999; Partanen et al. 2000; Siekmann and Lawson 2007; Tammela et al. 2008). Accordingly, a homozygous deletion of Vegfr3 leads to failure of cardiovascular development before the first lymphatic vessels develop from embryonic veins at E9.5 (Dumont et al. 1998). Intriguingly, the role of VEGFR3 in embryonic angiogenesis seems to be ligand-independent, as deletion of both of its identified ligands, VEGF-C and VEGF-D, led to the absence of lymphatic but not blood vasculature in E13.5 embryos (Haiko et al. 2008). Moreover, mutation of the VEGFR3 ligand-binding domain or kinase domain pre- vented lymphangiogenesis but not angiogenesis (Zhang et al. 2010). In the absence of ligand-induced VEGFR3 kinase activity, other kinases (such as the SRC kinases) activated by integrin signaling can phosphorylate the cytoplasmic tail of VEGFR3, providing docking sites for VEGFR3 downstream signaling components /Galvagni et al. 2010). However, experiments so far have shown that lymphangiogenesis is strictly dependent on an intact VEGF-C-VEGFR3 signaling pathway.

While Vegfr3 has been shown to be necessary for LEC proliferation, sprouting, and migration (Karkkainen et al. 2001), the role of VEGFR2 in LECs seems more contextdependent. The VEGFR2-specific ligand VEGF-E induced LEC proliferation but not sprouting, suggesting that VEGFR2 has a secondary role in the modulation of lymphatic vessel caliber (Wirzenius et al. 2007; Zarkada et al. 2015). However, Vegfr2 deletion had no effect on developmental lymphangiogenesis, whereas Vegfr3 expression was essential for postnatal lymphangiogenesis and even the maintenance of some lymphatic vessel segments in adult skin (Zarkada et al. 2015).

VEGF-C binding to VEGFR3 induces endocytosis of the ligand-receptor complex, which may be necessary for full activation of VEGFR3-derived signals. Ephrin B2, localized to cellular filopodia in active LECs, was necessary for VEGFR3 endocytosis after ligand binding and increased filopodia number and length in response to VEGF-C exposure (Wang et al. 2010). In line with this, deletion of the intracellular C-terminal PDZ domain of ephrin B2 led to defective expansion and pruning of the primary lymphatic capillary plexus, resulting in blunted lymphatic capillary sprouts (Makinen et al. 2005). Ephrin B2 was also needed for the internalization of VEGFR2 (Sawamiphak et al. 2010). Accordingly, antibody-mediated inhibition of ephrin B2 led to attenuation of tumor-associated lymphangiogenesis and angiogenesis (Abengozar et al. 2012). After its internalization, growth factor-activated VEGFR3 triggers several intracellular signal transduction pathways (for review, see Coso et al. 2014; Secker and Harvey 2015). The ubiquitin-binding adaptor proteins epsin 1 and epsin 2 bind to VEGFR3 and mediate its internalization and degradation, resulting in termination of VEGFR3 signaling. Interestingly, mice with LECspecific deficiency of epsin 1 and epsin 2 had dilated lymphatic capillaries, abnormally high VEGFR3 abundance in collecting lymphatics, immature lymphatic valves, and defective lymph drainage (Liu et al. 2014).

VEGFR3 activity is modulated by its coreceptor, neuropilin 2 (NRP2), initially identified as an axon guidance receptor, which is also expressed in lymphatic vessels and veins (Yuan et al. 2002). VEGF-C binds NRP2 directly, promoting its interaction with VEGFR3 (Karkkainen et al. 2001; Favier et al. 2006). Nrp2 deletion or antibodies blocking the NRP2-VEGF-C interaction attenuated LEC migration and sprouting but not proliferation (Fig. 1B,C; Caunt et al. 2008; Xu et al. 2010). Accordingly, lymphatic vessels in the dermis of Nrp2 mutant embryos are larger and less branched (Uchida et al. 2015), although this phenotype is partially compensated in adults (Yuan et al. 2002). A similar phenotype with increased cell 
proliferation but decreased branching was observed upon mutation of $T g f \beta r 1$ or $T g f \beta r 2$ (James et al. 2013). Interestingly, TGF $\beta$ up-regulates NRP2 and VEGFR3 levels, simultaneously inhibiting LEC proliferation in vitro, which suggests that TGF $\beta$-driven lymphatic vessel sprouting/branching is NRP2-dependent (James et al. 2013). It is curious that NRP2 signaling does not promote VEGFR3-dependent LEC proliferation; perhaps lymphatic vessel branching/sprouting requires a higher VEGFR3 activity threshold than LEC proliferation. On the other hand, NRP2 could be necessary for only some VEGFR3 downstream signaling pathways, similarly to NRP1, which is specifically required for full activation of the p38MAPK signaling pathway downstream from VEGFR2 (Kawamura et al. 2008).

According to Johns et al. (2016), the cell surface heparan sulfate proteoglycan syndecan-4 interacts with VEGFR3 and potentiates its activity. It was also suggested that the heparan sulfate side chains of syndecan-4 bind immature VEGF-C via the charged heparan sulfate side chains and that these could provide a tissue reservoir or sink of VEGF-C (Johns et al. 2016; Jha et al. 2017). In line with this, lymphatic endothelial-specific deletion of heparan sulfates leads to attenuation of tumor-induced lymphangiogenesis, possibly because of decreased VEGFR3 signaling (Johns et al. 2016). Strikingly, however, syndecan-4 deletion led to excessive expansion of lymphatic vasculature during embryonic development (Wang et al. 2016), suggesting that syndecan-4 is not needed for VEGFR3 signaling, at least in the developmental setting. Furthermore, a chimeric VEGF-C containing the VEGF homology domain of VEGF-C in fusion with the high-affinity heparan sulfate-binding domain of VEGF induced a unique lymphatic vessel growth pattern along blood vessels (Tammela et al. 2007). The syndecan-4 heparan sulfates could act as a reservoir or sink of VEGF-C in a context-dependent manner, and the CCBE1-ADAMTS3 complex could provide the required switch to activate the syndecan-4-bound latent VEGF-C (Jeltsch et al. 2014; Jha et al. 2017).

The integrin $\beta 1$ subunit has been shown to interact with VEGFR3 in response to LEC adhesion to fibronectin or VEGFR3 stimulation with VEGF-C (Fig. 1B,C). Formation of the integrin $\beta 1$-VEGFR3 complex increases VEGFR3 phosphorylation and LEC migration in vitro (Wang et al. 2001; Zhang et al. 2005). LECs are in contact with the ECM during lymphangiogenesis and with the basement membrane in mature quiescent lymphatic vessels; thus, the function of the VEGFR3-integrin $\beta 1$ interaction differs in these two settings. By binding to the ECM, integrins are able to translate changes in extracellular tension to cellular responses via outside-in signaling. Interestingly, interstitial pressure/edema also leads to VEGFR3 activation and lymphangiogenesis in an integrin $\beta 1$-dependent manner (see below; Planas-Paz et al. 2012). Recently, other cell surface transmembrane proteins, such as CLP24 and CLEC14a, have been shown to interact with VEGFR3, but their exact roles in lymphangiogenesis are not yet known (Saharinen et al. 2010; Lee et al. 2017).

\section{Lymphatic vessel sprouting}

Several principles of blood vessel sprouting apply also to lymphangiogenesis, although differences are evident. Blood vascular endothelial tip cells are considered to sample the microenvironment with long thin filopodia that guide the establishment of the leading BEC lamellopodia and the direction of vessel growth, whereas BEC proliferation (and thus sprout elongation) occurs most intensely in the vessel stalk (Gerhardt et al. 2003). In tracheal lymphatic vessels, most of the LEC proliferation in response to $M$. pulmonis-induced inflammation was found to occur $\sim 60 \mu \mathrm{m}$ behind the lymphatic capillary tip cell (Baluk et al. 2005), suggesting similarity between blood and lymphatic vessel growth.

In growing blood vessel sprouts, the endothelial tip cells have high VEGFR2 activity (Jakobsson et al. 2010; Costa et al. 2016). VEGFR2 activation induces expression of the membrane-bound delta-like ligand 4 (DLL4), especially in the tip cells, and subsequent NOTCH activation in the sprouts (Hellstrom et al. 2007; Lobov et al. 2007; Ubezio et al. 2016; Hasan et al. 2017; Pitulescu et al. 2017). DLL4 in turn suppresses further sprouting, as evidenced by hyperbranching of blood vasculature upon Dll4 deletion or attenuation of NOTCH signaling (Sainson et al. 2005; Hellstrom et al. 2007; Lobov et al. 2007; Suchting et al. 2007). Similarly, VEGF-C induces DLL4 expression in LECs (Zheng et al. 2011). Suppression of NOTCH signaling by a soluble DLL4, an inhibitor of $\mathrm{NOTCH}$ signaling, led to hypersprouting of lymphatic vessels in adult mouse skin (Zheng et al. 2011). Lymphangiogenesis triggered by Notch inhibition was suppressed by a VEGFR2-blocking antibody as well as soluble VEGF and VEGF-C/VEGF-D ligand traps (Zheng et al. 2011). In the embryonic dermis, deletion of Notch1 caused hyperbranching of the lymphatic vessels and increased LEC proliferation (Murtomaki et al. 2013; Fatima et al. 2014). However, D114 deletion in adult mice caused shortening of lacteal vessels, which are typically unbranched and may constantly renew in homeostatic conditions (Bernier-Latmani et al. 2015; Nurmi et al. 2015). Dl14 deletion had no effect on mature dermal lymphatic vessels (Bernier-Latmani et al. 2015). Antibody-mediated NOTCH inhibition in postnatal mice during the development of the dermal lymphatic network caused inhibition of both lymphatic vessel growth and sprouting (Niessen et al. 2011). In this context, inhibition of NOTCH signaling was associated with down-regulation of ephrin B2 (Niessen et al. 2011), which is necessary for VEGFR3 internalization and signaling (Wang et al. 2010). These experiments indicate that NOTCH signaling has context-dependent effects in lymphangiogenesis.

\section{Interstitial fluid pressure, edema, and flow regulate lymphangiogenesis}

One of the key functions of lymphatic vessels is to remove interstitial fluid and return it to the blood circulation. An obvious question is whether accumulation of interstitial fluid (and thus increased pressure) stimulates 
lymphangiogenesis. Indeed, expansion of the lymphatic network during development, inflammation, and hypertension correlates with interstitial fluid accumulation (Machnik et al. 2009; Planas-Paz et al. 2012; Kim et al. 2014). In mouse embryos, interstitial fluid pressure peaks at about E12.0, and this coincides with the proliferation of LECs and formation of lymph sacs and the associated superficial lymphatic plexus (Planas-Paz et al. 2012). Interstitial pressure was shown to stretch LECs and induce their proliferation in vivo, and, in vitro, stretch synergized with VEGF-C in stimulating LEC proliferation (Planas$\mathrm{Paz}$ et al. 2012). The shear stress associated with lymph flow has been shown to potentiate VEGF-C-induced LEC sprouting in two-dimensional and 3D cell cultures (Helm et al. 2005; Kim et al. 2016; Choi et al. 2017b). Recently, flow was shown to suppress NOTCH signaling via the calcium influx mediated by the ORAIl calcium channel. Accordingly, Orail calcium channel-deficient embryos displayed hypobranching of dermal lymphatic vessels (Choi et al. 2017b). Furthermore, VEGF expression by tumor cells drives peritumoral interstitial convection, which could potentially stimulate lymphangiogenesis associated with tumorigenesis (Dafni et al. 2002). Interstitial pressure and fluid flow also modulate the regeneration of lymphatic capillaries. Lymphangiogenesis associated with skin wound healing in mouse tails was attenuated upon decreased interstitial flow through the regenerating region, and the capacity of ectopic VEGF-C to induce lymphangiogenesis was blunted in conditions of decreased flow (Rutkowski et al. 2006; Goldman et al. 2007). It was suggested that the need for flow is related to the channeling of growth factor and protease cues (Boardman and Swartz 2003).

It seems that lymphatic vessel specification and identity are determined in part by the level of fluid shear stress. In Slp-76 (Lcp2) mutant mice, in which the access of blood into some lymphatic vessels leads to lymphatic vessel exposure to high shear stress, PROX1 is down-regulated and LECs start to display features of blood vascular endothelia (Abtahian et al. 2003; Chen et al. 2012a). In vitro, even low shear stress induces LEC alignment with the direction of flow in a pattern similar to the in vivo situation in lymphatic vessels ( $\mathrm{Ng}$ et al. 2004; Sabine et al. 2012). Upon oscillatory flow, which mimics turbulent flow in the valve-forming areas, cultured LECs adopt a cuboidal shape similar to that of valve-forming cells (Sabine et al. 2012). Interestingly, only the PROX1-high LECs respond to oscillatory flow, whereas all LECs respond to shear stress caused by laminar flow (Sabine et al. 2012). It is not known whether flow contributes to lymphangiogenesis in already lumenized sprouts by modulating LEC proliferation in the stalks of the sprouts.

A variety of fluid pressure/flow sensors has been implicated in lymphangiogenic responses. It has been suggested that interstitial fluid accumulation and increased pressure impacts the reorganization of stretched ECM, thereby affecting integrin $\beta 1$ and subsequent VEGFR3 activation in embryos (Fig. 1B,C; Planas-Paz et al. 2012). Interestingly, VEGFR3 may also provide a mechanosensory function when complexed with VE-cadherin (Coon et al. 2015), raising the possibility of interstitial pressure sensing at the level of LEC-LEC junctions, which mediate tension between the cells. The endothelial transmembrane protein PECAM1 (CD31) functions as a mechanosensor in BEC-BEC junctions of the blood vascular endothelium (Osawa et al. 2002; Tzima et al. 2005). Interestingly, Pecam1-deleted mouse embryos have increased branching of mesenteric lymphatics, suggesting that PECAM1 could provide a similar function also in the lymphatic vessels (Wang et al. 2016). Furthermore, loss of syndecan-4 or $\beta$-catenin function leads to defective lymphatic vasculature patterning in the embryonic mesentery and dermis, respectively (Cha et al. 2016; Wang et al. 2016). These mutant phenotypes may be caused by defective flow sensing, which leads to increased proliferation of LECs or lack of pruning of the lymphatic sprouts, resembling the defective blood vessel pruning in decreased flow conditions (for review, see Korn and Augustin 2015). Laminar flow has also been shown to induce ORAI1-dependent calcium signaling, which stimulated LEC proliferation and sprouting during development (Choi et al. 2017a,b). However, the actual sensor that activates ORAIl has not yet been identified. Mutations of mechanosensitive calcium-permeable channel PIEZO1 have been linked to hereditary lymphedema (Fotiou et al. 2015; Lukacs et al. 2015). Although the exact role of PIEZO1 in lymphatic function is still unclear, studies on blood vasculature have suggested a role for PIEZO1 in transducing shear stress to polarized BEC orientation (Li et al. 2014; Ranade et al. 2014). In addition, deletion of $P d k 1$ or $P d k 2$, which have been implicated in mechanosensitive calcium signaling, led to failure of thoracic duct development in zebrafish embryos and attenuated branching of cutaneous lymphatic vessels in mouse embryos (Coxam et al. 2014; Outeda et al. 2014). Although most of the in vivo investigations so far have focused on developmental lymphangiogenesis, it would be interesting to know whether similar mechanisms regulate regenerative lymphangiogenesis.

\section{Lymphatic vessel guidance by arteries and nerves}

As lymphatic vessels drain the tissue fluid extravasated from blood vessels, the codevelopment of these two vascular systems is critical. Indeed, large lymphatic collectors align with major blood vessels in mice and humans, indicating that the growth of the two vascular systems is interconnected (Fig. 1A; Sabin 1902). Lymphatic and blood vessels display close association already in the chorioallantonic membrane of chicken embryos (Oh et al. 1997). Furthermore, lymphatic vessel development is dependent on prior arteriogenesis in the mouse mesentery (Mahadevan et al. 2014). In zebrafish, a recently identified population of cells resembling LECs in the brain was shown to migrate along the mesencephalic vein during development; the cells remain positioned in close proximity to meningeal blood vessels in adult fish without forming a lumenized structure (Bower et al. 2017a; van Lessen et al. 2017; Venero Galanternik et al. 2017). Interestingly, migration of these LEC-resembling cells was shown to be 
vegfr3-, vegfc-, vegfd-, and ccbe1-dependent (Bower et al. 2017a; van Lessen et al. 2017). Whether this reflects Vegfc production by the BECs or the associated SMCs (see above; Fig. 1A) requires further investigation. Similarly, patterning of the first lymphatic vessels in zebrafish is dependent on LEC migration along intersegmental arteries whose mispatterning alters lymphatic vessel patterning, indicating that the blood vasculature provides guidance for the developing lymphatic vessels (Bussmann et al. 2010). The arterial chemokine Cxcl12 and its receptor, Cxcr4, in LECs provide such a guidance function in zebrafish (Cha et al. 2012; Zhuo et al. 2012). Consistent with this, a specific inhibitor of the CXCL12-CXCR4 interaction blocks suture-induced corneal lymphangiogenesis in mice (Du and Liu 2016).

Blood vessels can regulate lymphatic vessel growth and maintenance also via the peptide hormone adrenomedullin, which is essential for proper lymphatic vessel development. Accordingly, deletion of adrenomedullin or either of its two receptors, Calcrl or Ramp2, leads to an edematous embryonic phenotype (Fritz-Six et al. 2008; IchikawaShindo et al. 2008), whereas overexpression of adrenomedullin by tumor cells results in increased lymphangiogenesis (Karpinich et al. 2013). Adrenomedullin levels are regulated by the atypical chemokine receptor CXCR7, which acts as a sink of adrenomedullin. Because of this, Cxcr 7 deletion leads to increased adrenomedullin levels and hypersprouting of lymphatic vessels (Klein et al. 2014). Interestingly, CXCR7 is expressed predominantly in BECs, whereas CALCRL and RAMP2 are more prominent in LECs, and CXCR7 acts also as a sink for CXCL12 (Boldajipour et al. 2008; Fritz-Six et al. 2008). Thus, dynamic modulation of CXCL12, adrenomedullin, and CXCR7 levels in the two vascular systems could potentially regulate their alignment and separation from each other at later developmental stages (Boldajipour et al. 2008).

Although the major collecting lymphatic vessels accompany arteries, lymphatic capillaries display a distribution pattern that is distinct from blood vessels. The separation of these two networks is an active process that uses, for example, semaphorin $3 \mathrm{G}$, a repulsive cue in axon pathfinding (Uchida et al. 2015; Liu et al. 2016). In vitro, semaphorin $3 \mathrm{G}$ induces LEC contraction and repulsion, which is dependent on semaphorin $3 \mathrm{G}$ receptors plexin and NRP2 (Uchida et al. 2015; Liu et al. 2016). Developing arteries in the embryonic dermis express semaphorin $3 \mathrm{G}$, suggesting that the altered lymphatic pattern in semaphorin 3G-deleted mice results from failure of lymphatic vessel separation from the arteries (Fig. 1D; Uchida et al. 2015; Liu et al. 2016). The nonarterial semaphorins 3C and 3F may also inhibit lymphangiogenesis during development and tumorigenesis (Doci et al. 2015; Mumblat et al. 2015).

Although nerves have not been directly implicated in lymphatic vessel growth in mammals, it is well established that cutaneous neurons guide developing arteries in embryonic skin (Mukouyama et al. 2002). They could thus indirectly affect lymphatic guidance. In zebrafish, however, LECs migrate along motoneurons, which in turn are directed by netrin 1, secreted by the underlying muscle pioneers in the horizontal myoseptum. Both netrin 1 down-regulation and laser-mediated motoneuron ablation prevented proper LEC migration and the parachordal sprouting of LECs (Lim et al. 2011). Vegfc from the preformed dorsal aorta guides the axon growth of secondary motoneurons in zebrafish (Kwon et al. 2013). These examples indicate the existence of cross-talk between the developing neuronal and lymphatic vascular networks.

\section{Basement membranes in lymphangiogenesis}

Quiescent lymphatic vessels are invested with a basement membrane, which is very thin and porous around lymphatic capillaries, being thicker and continuous around the collector vessels (Sauter et al. 1998; Pflicke and Sixt 2009; Lutter et al. 2012). These differences reflect functional specialization of these two vessel types. The porous basement membrane allows leukocyte entry via LEC-LEC junctions into the lymphatic capillary lumen (Pflicke and Sixt 2009), whereas the basement membrane around collectors is critical for endothelial cell-SMC interactions, as in blood vessels (Lutter et al. 2012). The lymphatic vessel basement membrane is composed of LECexpressed laminin $\alpha 4 / 5, \beta 1 / 2$, and $\gamma 1$ chains; collagens IV and XVII; reelin; and nidogen 1 that cross-links the laminin and collagen layers (Vainionpaa et al. 2007; Pflicke and Sixt 2009; Lutter et al. 2012). The functional significance of the lymphatic vessel basement membrane and its constituents are less well known than in the case of blood vessel basement membranes. Embryoid bodies that have a mutation in the laminin $\gamma 1$ gene lack a structured basement membrane and have dilated blood vessels and altered vessel branching (Jakobsson et al. 2008). Deletion of the laminin a 4 gene in vivo led to blood vessel hypersprouting in mouse retinas in an integrin $\beta 1$-dependent manner (Stenzel et al. 2011). As in blood vessels, basement membranes seem to stabilize lymphatic vessels. Reelin was shown to be essential for lymphatic collector maturation via stabilization of interactions between LECs and SMCs (Lutter et al. 2012). Furthermore, basement membrane matrix (Matrigel) inhibited sprouting lymphangiogenesis in explants of the thoracic duct in vitro (Detry et al. 2012).

During angiogenesis, matrix metalloproteases digest basement membranes and the interstitial matrix, thus revealing new integrin-binding epitopes and releasing growth factors that facilitate sprout formation (Arroyo and Iruela-Arispe 2010). Thin and porous lymphatic capillary basement membranes should allow an interaction between LECs and the components of the interstitial matrix. Thus, the extension of LEC sprouts may be much less protease-dependent (for review, see Paupert et al. 2011). Indeed, LECs in general express fewer proteases than BECs (Petrova et al. 2002). Nevertheless, increased expression of matrix metalloproteinase 2 (MMP2) and MMP9 is associated with wound healing and FGF2-induced lymphangiogenesis (Chang et al. 2004; Rutkowski et al. 2006). MMP2 was also up-regulated in lymphangiogenesis in 
response to corneal injury, and $M m p 2$ deletion led to tortuous lymphatic capillaries in the cornea (Detry et al. 2012). In zebrafish, mmp2 deletion reduced the length of the thoracic duct, possibly via attenuated processing of collagen (Detry et al. 2012). In contrast, spontaneous lymphangiogenesis was observed in corneas of MTMMP1-deficient mice (Wong et al. 2016). These examples suggest that metalloproteases may control lymphangiogenesis, e.g., via modulation of basement membrane components and by exposing hidden matrix components.

\section{Integrins and the interstitial matrix in lymphatic sprouting}

During lymphangiogenesis, lymphatic vessel tip cells interact with fibrillar and provisional matrix components, such as collagen I and fibronectin, in the remodeling tissue. Several of these components are known to modulate lymphangiogenic responses. The ECM components that directly interact with integrins in LECs lead to activation of signal transduction pathways involved in the regulation of migration and proliferation (for review, see Chen et al. 2012 b). For example, injection of a collagen I gel stimulated lymphangiogenesis associated with wound healing in mice (Clavin et al. 2008), and the EDA epitope-containing fibronectin form, which is abundant in regenerating tissues, stimulated LEC proliferation in vitro (Ou et al. 2010).

Several integrins expressed in LECs are essential for lymphangiogenesis. The integrin $\alpha 9$ gene (ITGA9) is an important Proxl-regulated LEC signature gene (Petrova et al. 2002; Mishima et al. 2007). Mice deleted of the $\alpha 9$ subunit (Itga9) of integrin $\alpha 9 \beta 1$ failed to survive beyond postnatal day 12 due to development of chylothorax, which has also been reported in patients with missense mutations of the ITGA9 (Huang et al. 2000; Liao et al. 2002; Ma et al. 2008). $\alpha 9 \beta 1$ integrin is necessary for the formation of lymphatic valves; it acts via binding to the fibronectin EDA domain, emilin1, and polydom (Bazigou et al. 2009; Danussi et al. 2013; Karpanen et al. 2017; Morooka et al. 2017). Polydom deletion recapitulates the chylothorax phenotype of Itga9 mutant mice and also leads to severe defects in lymphatic vessel sprouting, which has not been reported for Itga9 mutants (Morooka et al. 2017). Furthermore, it was suggested that defective lymphatic vessel sprouting in Polydom-deficient mice depends on attenuated angiopoietin 2 signaling (Morooka et al. 2017).

Expression of the major fibronectin and collagen receptors is upregulated in LECs in lymphangiogenic conditions. The fibronectin receptor integrin $\alpha 5 \beta 1$ is induced in lymphangiogenic sprouts of inflamed tracheal mucous membranes, and small molecules that block a $5 \beta 1$ inhibited lymphangiogenesis but not angiogenesis associated with tracheal or corneal inflammation (Dietrich et al. 2007; Okazaki et al. 2009). The fibronectin and VCAM receptor $\alpha 4 \beta 1$ is up-regulated in lymphangiogenesis, and its genetic deletion or antibody-mediated inhibition attenuated tumor lymphangiogenesis (Garmy-Susini et al. 2010). Furthermore, collagen receptors integrin $\alpha 1 \beta 1$ and $\alpha 2 \beta 1$ were induced upon VEGF exposure in vitro, and antibodies against $\alpha 1 \beta 1$ and $\alpha 2 \beta 1$ attenuated wound healing-associated lymphatic vessel density in mice treated with VEGF-expressing implants (Hong et al. 2004). Inhibition of $\alpha 1 \beta 1$ also attenuated suture-induced inflammatory lymphangiogenesis (Grimaldo et al. 2011). Lymphangiogenic integrins contain the $\beta 1$ chain, which interacts with VEGFR3 and stimulates its activity (Fig. 1B,C); thus, the above results could be mediated at least in part by regulation of VEGFR3 activation.

\section{Outlook}

Recent findings in the field of lymphangiogenesis and lymphatic biology include the identification of meningeal lymphatic vessels (Aspelund et al. 2015; Louveau et al. 2015) and finding of nonvenous endothelial cell contribution to lymphatic vessel growth in various tissues (Klotz et al. 2015; Martinez-Corral et al. 2015; Stanczuk et al. 2015). These will undoubtedly provide additional insights for our understanding of the normal and pathological functions of lymphatic vasculature. Improvements in genetic reporters and lineage tracing tools and the ongoing deep and single-cell RNA sequencing should allow the identification of distinct molecular signatures of various types of lymphatic vessels in different organs as well as identification of novel lymphatic vessel-specific markers, which can be used to develop highly specific lineage tracing and Credeleter mouse strains. Together with advanced wholemount imaging techniques, these tools should enable studies of lymphangiogenesis in the context of hierarchical lymphatic networks, which may reveal unexpected heterogeneity among seemingly similar LECs and allow studies on lymphatic vessel interactions with other anatomical structures. The possibility of postnatal manipulation of lymphatic vessel development in vivo allows studies of molecules that are essential for vascular growth and indispensable for embryonic development. These studies should provide additional insights into the general mechanisms of vascular growth and disease.

The importance of lymphatic vessels has been shown in the pathogenesis of several diseases, and modulation of lymphangiogenesis provides opportunities for therapeutic interventions. In preclinical models, inhibition of lymphangiogenesis decreases tumor dissemination, whereas stimulation of lymphangiogenesis results in enhanced resolution of inflammation. The studies done so far have targeted VEGFR3 ligand availability or signaling activity directly. However, detailed knowledge of other paracrine and pericellular mechanisms of lymphangiogenesis should provide additional possibilities to treat diseases whose pathogenesis involves lymphatic vessels.

\section{Acknowledgments}

We apologize to all those whose work is not cited due to the space constraints. We thank Dr. M. Jeltsch for critical reading of the manuscript, Dr. G. Zarkada for trachea and tail skin images, and Dr. I. Martinez-Corral for the mesentery and embryo skin 
images. This work was supported by the Jenny and Antti Wihuri Foundation, the Jane and Aatos Erkko Foundation, the Academy of Finland (Centre of Excellence Program 2014-2019 [271845 and 307366]), the Leducq Foundation (11CVD03), the European Research Council (ERC) under the European Union's Horizon 2020 Research and Innovation Programme (under grant agreement no. 743155), the Sigrid Juselius Foundation, and the Finnish Cancer Society (all to K.A.). K.V. was supported by an academy of Finland post-doctoral research grant (287853) and the University of Helsinki three-year research grant. S.K. was supported by a Swiss National Science Foundation Advanced Postdoc.Mobility grant (P300PB_164732). T.M. was supported by the Swedish Research Council and the European Research Council (ERC-2014CoG-646849).

\section{References}

Abengozar MA, de Frutos S, Ferreiro S, Soriano J, Perez-Martinez M, Olmeda D, Marenchino M, Canamero M, Ortega S, Megias D, et al. 2012. Blocking ephrinB2 with highly specific antibodies inhibits angiogenesis, lymphangiogenesis, and tumor growth. Blood 119: 4565-4576.

Abtahian F, Guerriero A, Sebzda E, Lu MM, Zhou R, Mocsai A, Myers EE, Huang B, Jackson DG, Ferrari VA, et al. 2003. Regulation of blood and lymphatic vascular separation by signaling proteins SLP-76 and Syk. Science 299: 247-251.

Achen MG, Williams RA, Minekus MP, Thornton GE, Stenvers K, Rogers PA, Lederman F, Roufail S, Stacker SA. 2001. Localization of vascular endothelial growth factor-D in malignant melanoma suggests a role in tumour angiogenesis. I Pathol 193: $147-154$.

Adachi Y, Nakamura H, Kitamura Y, Taniguchi Y, Araki K, Shomori K, Horie Y, Kurozawa Y, Ito H, Hayashi K. 2007. Lymphatic vessel density in pulmonary adenocarcinoma immunohistochemically evaluated with anti-podoplanin or anti-D2-40 antibody is correlated with lymphatic invasion or lymph node metastases. Pathol Int 57: 171-177.

Aebischer D, Iolyeva M, Halin C. 2014. The inflammatory response of lymphatic endothelium. Angiogenesis 17: 383-393.

Alders M, Hogan BM, Gjini E, Salehi F, Al-Gazali L, Hennekam EA, Holmberg EE, Mannens MM, Mulder MF, Offerhaus GJ, et al. 2009. Mutations in CCBE1 cause generalized lymph vessel dysplasia in humans. Nat Genet 41: 1272-1274.

Alders M, Mendola A, Ades L, Al Gazali L, Bellini C, Dallapiccola B, Edery P, Frank U, Hornshuh F, Huisman SA, et al. 2013. Evaluation of clinical manifestations in patients with severe lymphedema with and without CCBE1 mutations. Mol Syndromol 4: 107-113.

Alitalo K. 2011. The lymphatic vasculature in disease. Nat Med 17: 1371-1380.

Arroyo AG, Iruela-Arispe ML. 2010. Extracellular matrix, inflammation, and the angiogenic response. Cardiovasc Res 86: 226-235.

Aspelund A, Tammela T, Antila S, Nurmi H, Leppanen VM, Zarkada G, Stanczuk L, Francois M, Makinen T, Saharinen P, et al. 2014. The Schlemm's canal is a VEGF-C/VEGFR-3-responsive lymphatic-like vessel. J Clin Invest 124: 3975-3986.

Aspelund A, Antila S, Proulx ST, Karlsen TV, Karaman S, Detmar M, Wiig H, Alitalo K. 2015. A dural lymphatic vascular system that drains brain interstitial fluid and macromolecules. I Exp Med 212: 991-999.

Aspelund A, Robciuc MR, Karaman S, Makinen T, Alitalo K. 2016. Lymphatic system in cardiovascular medicine. Circ Res 118: 515-530.
Astin JW, Haggerty MJ, Okuda KS, Le Guen L, Misa JP, Tromp A, Hogan BM, Crosier KE, Crosier PS. 2014. Vegfd can compensate for loss of Vegfc in zebrafish facial lymphatic sprouting. Development 141: 2680-2690.

Avraham T, Daluvoy S, Zampell J, Yan A, Haviv YS, Rockson SG, Mehrara BJ. 2010. Blockade of transforming growth factor- $\beta 1$ accelerates lymphatic regeneration during wound repair. Am J Pathol 177: 3202-3214.

Baldwin ME, Halford MM, Roufail S, Williams RA, Hibbs ML, Grail D, Kubo H, Stacker SA, Achen MG. 2005. Vascular endothelial growth factor D is dispensable for development of the lymphatic system. Mol Cell Biol 25: 2441-2449.

Baluk P, Tammela T, Ator E, Lyubynska N, Achen MG, Hicklin DJ, Jeltsch M, Petrova TV, Pytowski B, Stacker SA, et al. 2005. Pathogenesis of persistent lymphatic vessel hyperplasia in chronic airway inflammation. J Clin Invest 115: 247-257.

Bazigou E, Makinen T. 2013. Flow control in our vessels: vascular valves make sure there is no way back. Cell Mol Life Sci 70: 1055-1066.

Bazigou E, Xie S, Chen C, Weston A, Miura N, Sorokin L, Adams R, Muro AF, Sheppard D, Makinen T. 2009. Integrin- $\alpha 9$ is required for fibronectin matrix assembly during lymphatic valve morphogenesis. Dev Cell 17: 175-186.

Beasley NJ, Prevo R, Banerii S, Leek RD, Moore J, van Trappen P, Cox G, Harris AL, Jackson DG. 2002. Intratumoral lymphangiogenesis and lymph node metastasis in head and neck cancer. Cancer Res 62: 1315-1320.

Bernier-Latmani J, Cisarovsky C, Demir CS, Bruand M, Jaquet M, Davanture S, Ragusa S, Siegert S, Dormond O, Benedito R, et al. 2015. DLL4 promotes continuous adult intestinal lacteal regeneration and dietary fat transport. I Clin Invest 125: 4572-4586.

Bertozzi CC, Schmaier AA, Mericko P, Hess PR, Zou Z, Chen M, Chen CY, Xu B, Lu MM, Zhou D, et al. 2010. Platelets regulate lymphatic vascular development through CLEC-2-SLP-76 signaling. Blood 116: 661-670.

Betterman KL, Harvey NL. 2016. The lymphatic vasculature: development and role in shaping immunity. Immunol Rev 271: 276-292.

Bjorndahl M, Cao R, Nissen LJ, Clasper S, Johnson LA, Xue Y, Zhou Z, Jackson D, Hansen AJ, Cao Y. 2005. Insulin-like growth factors 1 and 2 induce lymphangiogenesis in vivo. Proc Natl Acad Sci 102: 15593-15598.

Boardman KC, Swartz MA. 2003. Interstitial flow as a guide for lymphangiogenesis. Circ Res 92: 801-808.

Boldajipour B, Mahabaleshwar H, Kardash E, Reichman-Fried M, Blaser H, Minina S, Wilson D, Xu Q, Raz E. 2008. Control of chemokine-guided cell migration by ligand sequestration. Cell 132: 463-473.

Bos FL, Caunt M, Peterson-Maduro J, Planas-Paz L, Kowalski J, Karpanen T, van Impel A, Tong R, Ernst JA, Korving J, et al. 2011. CCBE1 is essential for mammalian lymphatic vascular development and enhances the lymphangiogenic effect of vascular endothelial growth factor-C in vivo. Circ Res 109: 486-491.

Bower NI, Koltowska K, Pichol-Thievend C, Virshup I, Paterson S, Lagendijk AK, Wang W, Lindsey BW, Bent SJ, Baek S, et al. 2017a. Mural lymphatic endothelial cells regulate meningeal angiogenesis in the zebrafish. Nat Neurosci 20: 774-783.

Bower NI, Vogrin AJ, Le Guen L, Chen H, Stacker SA, Achen MG, Hogan BM. 2017b. Vegfd modulates both angiogenesis and lymphangiogenesis during zebrafish embryonic development. Development 144: 507-518. 
Brideau G, Makinen MJ, Elamaa H, Tu H, Nilsson G, Alitalo K, Pihlajaniemi T, Heljasvaara R. 2007. Endostatin overexpression inhibits lymphangiogenesis and lymph node metastasis in mice. Cancer Res 67: 11528-11535.

Brouillard P, Boon L, Vikkula M. 2014. Genetics of lymphatic anomalies. J Clin Invest 124: 898-904.

Bui HM, Enis D, Robciuc MR, Nurmi HJ, Cohen J, Chen M, Yang Y, Dhillon V, Johnson K, Zhang H, et al. 2016. Proteolytic activation defines distinct lymphangiogenic mechanisms for VEGFC and VEGFD. J Clin Invest 126: 2167-2180.

Bussmann J, Bos FL, Urasaki A, Kawakami K, Duckers HJ, Schulte-Merker S. 2010. Arteries provide essential guidance cues for lymphatic endothelial cells in the zebrafish trunk. Development 137: 2653-2657.

Cao R, Bjorndahl MA, Religa P, Clasper S, Garvin S, Galter D, Meister B, Ikomi F, Tritsaris K, Dissing S, et al. 2004a. PDGF-BB induces intratumoral lymphangiogenesis and promotes lymphatic metastasis. Cancer Cell 6: 333-345.

Cao R, Eriksson A, Kubo H, Alitalo K, Cao Y, Thyberg J. 2004b. Comparative evaluation of FGF-2-, VEGF-A-, and VEGF-C-induced angiogenesis, lymphangiogenesis, vascular fenestrations, and permeability. Circ Res 94: 664-670.

Cao R, Bjorndahl MA, Gallego MI, Chen S, Religa P, Hansen AJ, Cao Y. 2006. Hepatocyte growth factor is a lymphangiogenic factor with an indirect mechanism of action. Blood 107: 3531-3536.

Caunt M, Mak J, Liang WC, Stawicki S, Pan Q, Tong RK, Kowalski J, Ho C, Reslan HB, Ross J, et al. 2008. Blocking neuropilin2 function inhibits tumor cell metastasis. Cancer Cell 13: 331-342.

Cha YR, Fujita M, Butler M, Isogai S, Kochhan E, Siekmann AF, Weinstein BM. 2012. Chemokine signaling directs trunk lymphatic network formation along the preexisting blood vasculature. Dev Cell 22: 824-836.

Cha B, Geng X, Mahamud MR, Fu J, Mukherjee A, Kim Y, Jho EH, Kim TH, Kahn ML, Xia L, et al. 2016. Mechanotransduction activates canonical $\mathrm{Wnt} / \beta$-catenin signaling to promote lymphatic vascular patterning and the development of lymphatic and lymphovenous valves. Genes Dev 30: 1454-1469.

Chang LK, Garcia-Cardena G, Farnebo F, Fannon M, Chen EJ, Butterfield C, Moses MA, Mulligan RC, Folkman J, Kaipainen A. 2004. Dose-dependent response of FGF-2 for lymphangiogenesis. Proc Natl Acad Sci 101: 11658-11663.

Chen L, Hamrah P, Cursiefen C, Zhang Q, Pytowski B, Streilein JW, Dana MR. 2004. Vascular endothelial growth factor receptor-3 mediates induction of corneal alloimmunity. Nat Med 10: $813-815$.

Chen CY, Bertozzi C, Zou Z, Yuan L, Lee JS, Lu M, Stachelek SJ, Srinivasan S, Guo L, Vicente A, et al. 2012a. Blood flow reprograms lymphatic vessels to blood vessels. J Clin Invest 122: 2006-2017.

Chen J, Alexander JS, Orr AW. 2012b. Integrins and their extracellular matrix ligands in lymphangiogenesis and lymph node metastasis. Int J Cell Biol 2012: 853703.

Choi D, Park E, Jung E, Seong YJ, Hong M, Lee S, Burford J, Gyarmati G, Peti-Peterdi J, Srikanth S, et al. 2017a. ORAI1 activates proliferation of lymphatic endothelial cells in response to laminar flow through Kruppel-like factors 2 and 4. Circ Res 120: 1426-1439.

Choi D, Park E, Jung E, Seong YJ, Yoo J, Lee E, Hong M, Lee S, Ishida H, Burford J, et al. 2017b. Laminar flow downregulates Notch activity to promote lymphatic sprouting. I Clin Invest 127: 1225-1240.

Clavin NW, Avraham T, Fernandez J, Daluvoy SV, Soares MA, Chaudhry A, Mehrara BJ. 2008. TGF- $\beta 1$ is a negative regulator of lymphatic regeneration during wound repair. Am I Physiol Heart Circ Physiol 295: H2113-H2127.

Connell F, Kalidas K, Ostergaard P, Brice G, Homfray T, Roberts L, Bunyan DJ, Mitton S, Mansour S, Mortimer P, et al. 2010. Linkage and sequence analysis indicate that CCBE1 is mutated in recessively inherited generalised lymphatic dysplasia. Hum Genet 127: 231-241.

Coon BG, Baeyens N, Han J, Budatha M, Ross TD, Fang JS, Yun S, Thomas JL, Schwartz MA. 2015. Intramembrane binding of VE-cadherin to VEGFR2 and VEGFR3 assembles the endothelial mechanosensory complex. J Cell Biol 208: 975-986.

Coso S, Bovay E, Petrova TV. 2014. Pressing the right buttons: signaling in lymphangiogenesis. Blood 123: 2614-2624.

Costa G, Harrington KI, Lovegrove HE, Page DJ, Chakravartula S, Bentley K, Herbert SP. 2016. Asymmetric division coordinates collective cell migration in angiogenesis. Nat Cell Biol 18: 1292-1301.

Coxam B, Sabine A, Bower NI, Smith KA, Pichol-Thievend C, Skoczylas R, Astin JW, Frampton E, Jaquet M, Crosier PS, et al. 2014. Pkd1 regulates lymphatic vascular morphogenesis during development. Cell Rep 7: 623-633.

Cursiefen C, Chen L, Borges LP, Jackson D, Cao J, Radziejewski C, D'Amore PA, Dana MR, Wiegand SI, Streilein JW. 2004. VEGF-A stimulates lymphangiogenesis and hemangiogenesis in inflammatory neovascularization via macrophage recruitment. J Clin Invest 113: 1040-1050.

Cursiefen C, Maruyama K, Jackson DG, Streilein JW, Kruse FE. 2006. Time course of angiogenesis and lymphangiogenesis after brief corneal inflammation. Cornea 25: 443-447.

Cursiefen C, Maruyama K, Bock F, Saban D, Sadrai Z, Lawler J, Dana R, Masli S. 2011. Thrombospondin 1 inhibits inflammatory lymphangiogenesis by CD36 ligation on monocytes. I Exp Med 208: 1083-1092.

Dadras SS, Paul T, Bertoncini J, Brown LF, Muzikansky A, Jackson DG, Ellwanger U, Garbe C, Mihm MC, Detmar M. 2003. Tumor lymphangiogenesis: a novel prognostic indicator for cutaneous melanoma metastasis and survival. Am J Pathol 162: 1951-1960.

Dadras SS, Lange-Asschenfeldt B, Velasco P, Nguyen L, Vora A, Muzikansky A, Jahnke K, Hauschild A, Hirakawa S, Mihm $\mathrm{MC}$, et al. 2005. Tumor lymphangiogenesis predicts melanoma metastasis to sentinel lymph nodes. Mod Pathol 18: 1232-1242.

Dafni H, Israely T, Bhujwalla ZM, Benjamin LE, Neeman M. 2002. Overexpression of vascular endothelial growth factor 165 drives peritumor interstitial convection and induces lymphatic drain: magnetic resonance imaging, confocal microscopy, and histological tracking of triple-labeled albumin. Cancer Res 62: 6731-6739.

Danussi C, Del Bel Belluz L, Pivetta E, Modica TM, Muro A, Wassermann B, Doliana R, Sabatelli P, Colombatti A, Spessotto P. 2013. EMILIN1/ $\alpha 9 \beta 1$ integrin interaction is crucial in lymphatic valve formation and maintenance. Mol Cell Biol 33: 4381-4394.

Dashkevich A, Raissadati A, Syrjala SO, Zarkada G, Keranen MA, Tuuminen R, Krebs R, Anisimov A, Jeltsch M, Leppanen VM, et al. 2016. Ischemia-reperfusion injury enhances lymphatic endothelial VEGFR3 and rejection in cardiac allografts. Am J Transplant 16: 1160-1172.

Detry B, Erpicum C, Paupert J, Blacher S, Maillard C, Bruyere F, Pendeville H, Remacle T, Lambert V, Balsat C, et al. 2012. Matrix metalloproteinase-2 governs lymphatic vessel formation as an interstitial collagenase. Blood 119: 5048-5056.

Dietrich T, Onderka J, Bock F, Kruse FE, Vossmeyer D, Stragies R, Zahn G, Cursiefen C. 2007. Inhibition of inflammatory 
lymphangiogenesis by integrin a5 blockade. Am J Pathol 171: 361-372.

Dietrich T, Bock F, Yuen D, Hos D, Bachmann BO, Zahn G, Wiegand S, Chen L, Cursiefen C. 2010. Cutting edge: lymphatic vessels, not blood vessels, primarily mediate immune rejections after transplantation. J Immunol 184: 535-539.

Dixelius J, Makinen T, Wirzenius M, Karkkainen MJ, Wernstedt C, Alitalo K, Claesson-Welsh L. 2003. Ligand-induced vascular endothelial growth factor receptor-3 (VEGFR-3) heterodimerization with VEGFR-2 in primary lymphatic endothelial cells regulates tyrosine phosphorylation sites. I Biol Chem 278: 40973-40979.

Doci CL, Mikelis CM, Lionakis MS, Molinolo AA, Gutkind JS. 2015. Genetic identification of SEMA3F as an antilymphangiogenic metastasis suppressor gene in head and neck squamous carcinoma. Cancer Res 75: 2937-2948.

Doekhie FS, Morreau H, de Bock GH, Speetjens FM, DekkerEnsink NG, Putter H, van de Velde CJ, Tollenaar RA, Kuppen PJ. 2008. Sialyl Lewis X expression and lymphatic microvessel density in primary tumors of node-negative colorectal cancer patients predict disease recurrence. Cancer Microenviron 1: 141-151.

Du LL, Liu P. 2016. CXCL12/CXCR4 axis regulates neovascularization and lymphangiogenesis in sutured corneas in mice. Mol Med Rep 13: 4987-4994.

Dumont DJ, Jussila L, Taipale J, Lymboussaki A, Mustonen T, Pajusola K, Breitman M, Alitalo K. 1998. Cardiovascular failure in mouse embryos deficient in VEGF receptor-3. Science 282: 946-949.

Enholm B, Paavonen K, Ristimaki A, Kumar V, Gunji Y, Klefstrom J, Kivinen L, Laiho M, Olofsson B, Joukov V, et al. 1997. Comparison of VEGF, VEGF-B, VEGF-C and Ang-1 mRNA regulation by serum, growth factors, oncoproteins and hypoxia. Oncogene 14: 2475-2483.

Fatima A, Culver A, Culver F, Liu T, Dietz WH, Thomson BR, Hadjantonakis AK, Quaggin SE, Kume T. 2014. Murine Notch1 is required for lymphatic vascular morphogenesis during development. Dev Dyn 243: 957-964.

Fankhauser M, Broggi MAS, Potin L, Bordry N, Jeanbart L, Lund AW, Da Costa E, Hauert S, Rincon-Restrepo M, Tremblay C, et al. 2017. Tumor lymphangiogenesis promotes $T$ cell infiltration and potentiates immunotherapy in melanoma. Sci Transl Med 9: eaal4712.

Favier B, Alam A, Barron P, Bonnin J, Laboudie P, Fons P, Mandron $M$, Herault JP, Neufeld G, Savi P, et al. 2006. Neuropilin-2 interacts with VEGFR-2 and VEGFR-3 and promotes human endothelial cell survival and migration. Blood 108: 1243-1250.

Fernandes RJ, Hirohata S, Engle JM, Colige A, Cohn DH, Eyre DR, Apte SS. 2001. Procollagen II amino propeptide processing by ADAMTS-3. Insights on dermatosparaxis. I Biol Chem 276: 31502-31509.

Fotiou E, Martin-Almedina S, Simpson MA, Lin S, Gordon K, Brice G, Atton G, Jeffery I, Rees DC, Mignot C, et al. 2015. Novel mutations in PIEZO1 cause an autosomal recessive generalized lymphatic dysplasia with non-immune hydrops fetalis. Nat Commun 6: 8085 .

Francois M, Caprini A, Hosking B, Orsenigo F, Wilhelm D, Browne C, Paavonen K, Karnezis T, Shayan R, Downes M, et al. 2008. Sox 18 induces development of the lymphatic vasculature in mice. Nature 456: 643-647.

Fritz-Six KL, Dunworth WP, Li M, Caron KM. 2008. Adrenomedullin signaling is necessary for murine lymphatic vascular development. J Clin Invest 118: 40-50.
Gale NW, Thurston G, Hackett SF, Renard R, Wang Q, McClain J, Martin C, Witte C, Witte MH, Jackson D, et al. 2002. Angiopoietin-2 is required for postnatal angiogenesis and lymphatic patterning, and only the latter role is rescued by Angiopoietin1. Dev Cell 3: 411-423.

Galon J, Costes A, Sanchez-Cabo F, Kirilovsky A, Mlecnik B, Lagorce-Pages C, Tosolini M, Camus M, Berger A, Wind P, et al. 2006. Type, density, and location of immune cells within human colorectal tumors predict clinical outcome. Science 313: 1960-1964.

Galvagni F, Pennacchini S, Salameh A, Rocchigiani M, Neri F, Orlandini M, Petraglia F, Gotta S, Sardone GL, Matteucci G, et al. 2010. Endothelial cell adhesion to the extracellular matrix induces c-Src-dependent VEGFR-3 phosphorylation without the activation of the receptor intrinsic kinase activity. Circ Res 106: 1839-1848.

Garmy-Susini B, Avraamides CJ, Schmid MC, Foubert P, Ellies LG, Barnes L, Feral C, Papayannopoulou T, Lowy A, Blair $\mathrm{SL}$, et al. 2010. Integrin $\alpha 4 \beta 1$ signaling is required for lymphangiogenesis and tumor metastasis. Cancer Res 70: 3042-3051.

Gerhardt H, Golding M, Fruttiger M, Ruhrberg C, Lundkvist A, Abramsson A, Jeltsch M, Mitchell C, Alitalo K, Shima D, et al. 2003. VEGF guides angiogenic sprouting utilizing endothelial tip cell filopodia. J Cell Biol 161: 1163-1177.

Gibot L, Galbraith T, Kloos B, Das S, Lacroix DA, Auger FA, Skobe M. 2016. Cell-based approach for 3D reconstruction of lymphatic capillaries in vitro reveals distinct functions of HGF and VEGF-C in lymphangiogenesis. Biomaterials 78: 129-139.

Goldman J, Conley KA, Raehl A, Bondy DM, Pytowski B, Swartz MA, Rutkowski JM, Jaroch DB, Ongstad EL. 2007. Regulation of lymphatic capillary regeneration by interstitial flow in skin. Am I Physiol Heart Circ Physiol 292: H2176-H2183.

Gordon EJ, Rao S, Pollard JW, Nutt SL, Lang RA, Harvey NL. 2010. Macrophages define dermal lymphatic vessel calibre during development by regulating lymphatic endothelial cell proliferation. Development 137: 3899-3910.

Gordon K, Schulte D, Brice G, Simpson MA, Roukens MG, van Impel A, Connell F, Kalidas K, Jeffery S, Mortimer PS, et al. 2013. Mutation in vascular endothelial growth factor-C, a ligand for vascular endothelial growth factor receptor-3, is associated with autosomal dominant milroy-like primary lymphedema. Circ Res 112: 956-960.

Grimaldo S, Yuen D, Ecoiffier T, Chen L. 2011. Very late antigen1 mediates corneal lymphangiogenesis. Invest Ophthalmol Vis Sci 52: 4808-4812.

Guo R, Zhou Q, Proulx ST, Wood R, Ji RC, Ritchlin CT, Pytowski B, Zhu Z, Wang YJ, Schwarz EM, et al. 2009. Inhibition of lymphangiogenesis and lymphatic drainage via vascular endothelial growth factor receptor 3 blockade increases the severity of inflammation in a mouse model of chronic inflammatory arthritis. Arthritis Rheum 60: 2666-2676.

Hagerling R, Pollmann C, Andreas M, Schmidt C, Nurmi H, Adams RH, Alitalo K, Andresen V, Schulte-Merker S, Kiefer F. 2013. A novel multistep mechanism for initial lymphangiogenesis in mouse embryos based on ultramicroscopy. EMBO J 32: 629-644.

Haiko P, Makinen T, Keskitalo S, Taipale J, Karkkainen MJ, Baldwin ME, Stacker SA, Achen MG, Alitalo K. 2008. Deletion of vascular endothelial growth factor $\mathrm{C}$ (VEGF-C) and VEGF-D is not equivalent to VEGF receptor 3 deletion in mouse embryos. Mol Cell Biol 28: 4843-4850.

Hall KL, Volk-Draper LD, Flister MJ, Ran S. 2012. New model of macrophage acquisition of the lymphatic endothelial phenotype. PLoS One 7: e31794. 
Hasan SS, Tsaryk R, Lange M, Wisniewski L, Moore JC, Lawson ND, Wojciechowska K, Schnittler H, Siekmann AF. 2017. Endothelial Notch signalling limits angiogenesis via control of artery formation. Nat Cell Biol 19: 928-940.

He Y, Kozaki K, Karpanen T, Koshikawa K, Yla-Herttuala S, Takahashi T, Alitalo K. 2002. Suppression of tumor lymphangiogenesis and lymph node metastasis by blocking vascular endothelial growth factor receptor 3 signaling. I Natl Cancer Inst 94: 819-825.

He Y, Rajantie I, Pajusola K, Jeltsch M, Holopainen T, Yla-Herttuala S, Harding T, Jooss K, Takahashi T, Alitalo K. 2005. Vascular endothelial cell growth factor receptor 3-mediated activation of lymphatic endothelium is crucial for tumor cell entry and spread via lymphatic vessels. Cancer Res 65: 4739-4746.

Hellstrom M, Phng LK, Hofmann JJ, Wallgard E, Coultas L, Lindblom P, Alva J, Nilsson AK, Karlsson L, Gaiano N, et al. 2007. Dll4 signalling through Notch1 regulates formation of tip cells during angiogenesis. Nature 445: 776-780.

Helm CL, Fleury ME, Zisch AH, Boschetti F, Swartz MA. 2005. Synergy between interstitial flow and VEGF directs capillary morphogenesis in vitro through a gradient amplification mechanism. Proc Natl Acad Sci 102: 15779-15784.

Hirai S, Naito M, Terayama H, Qu N, Kuerban M, Musha M, Itoh M. 2013. Lymphangiogenesis in chronic inflammation in the testis. Andrology 1: 147-154.

Hogan BM, Bos FL, Bussmann J, Witte M, Chi NC, Duckers HJ, Schulte-Merker S. 2009. Ccbe1 is required for embryonic lymphangiogenesis and venous sprouting. Nat Genet 41: 396-398.

Hong YK, Lange-Asschenfeldt B, Velasco P, Hirakawa S, Kunstfeld R, Brown LF, Bohlen P, Senger DR, Detmar M. 2004. VEGF-A promotes tissue repair-associated lymphatic vessel formation via VEGFR-2 and the $\alpha 1 \beta 1$ and $\alpha 2 \beta 1$ integrins. FASEB I 18: 1111-1113.

Huang XZ, Wu JF, Ferrando R, Lee JH, Wang YL, Farese RV Jr, Sheppard D. 2000. Fatal bilateral chylothorax in mice lacking the integrin a9ß1. Mol Cell Biol 20: 5208-5215.

Huggenberger R, Siddiqui SS, Brander D, Ullmann S, Zimmermann K, Antsiferova M, Werner S, Alitalo K, Detmar M. 2011. An important role of lymphatic vessel activation in limiting acute inflammation. Blood 117: 4667-4678.

Ichikawa-Shindo Y, Sakurai T, Kamiyoshi A, Kawate H, Iinuma N, Yoshizawa T, Koyama T, Fukuchi J, Iimuro S, Moriyama $\mathrm{N}$, et al. 2008. The GPCR modulator protein RAMP2 is essential for angiogenesis and vascular integrity. J Clin Invest 118: 29-39.

Irrthum A, Karkkainen MJ, Devriendt K, Alitalo K, Vikkula M. 2000. Congenital hereditary lymphedema caused by a mutation that inactivates VEGFR3 tyrosine kinase. Am I Hum Genet 67: 295-301.

Isogai S, Lawson ND, Torrealday S, Horiguchi M, Weinstein BM. 2003. Angiogenic network formation in the developing vertebrate trunk. Development 130: 5281-5290.

Jakobsson L, Domogatskaya A, Tryggvason K, Edgar D, ClaessonWelsh L. 2008. Laminin deposition is dispensable for vasculogenesis but regulates blood vessel diameter independent of flow. FASEB J 22: 1530-1539.

Jakobsson L, Franco CA, Bentley K, Collins RT, Ponsioen B, Aspalter IM, Rosewell I, Busse M, Thurston G, Medvinsky A, et al. 2010. Endothelial cells dynamically compete for the tip cell position during angiogenic sprouting. Nat Cell Biol 12: 943-953.

James JM, Nalbandian A, Mukouyama YS. 2013. TGF $\beta$ signaling is required for sprouting lymphangiogenesis during lymphatic network development in the skin. Development 140: 3903-3914.

Janssen L, Dupont L, Bekhouche M, Noel A, Leduc C, Voz M, Peers B, Cataldo D, Apte SS, Dubail J, et al. 2016. ADAMTS3 activity is mandatory for embryonic lymphangiogenesis and regulates placental angiogenesis. Angiogenesis 19: 53-65.

Jeltsch M, Jha SK, Tvorogov D, Anisimov A, Leppanen VM, Holopainen T, Kivela R, Ortega S, Karpanen T, Alitalo K. 2014. CCBE1 enhances lymphangiogenesis via $\mathrm{A}$ disintegrin and metalloprotease with thrombospondin motifs-3-mediated vascular endothelial growth factor-C activation. Circulation 129: 1962-1971.

Jha SK, Rauniyar K, Karpanen T, Leppanen VM, Brouillard P, Vikkula M, Alitalo K, Jeltsch M. 2017. Efficient activation of the lymphangiogenic growth factor VEGF-C requires the C-terminal domain of VEGF-C and the N-terminal domain of CCBE1. Sci Rep 7: 4916.

Jiang S, Bailey AS, Goldman DC, Swain JR, Wong MH, Streeter PR, Fleming WH. 2008. Hematopoietic stem cells contribute to lymphatic endothelium. PLoS One 3: e3812.

Johns SC, Yin X, Jeltsch M, Bishop JR, Schuksz M, El Ghazal R, Wilcox-Adelman SA, Alitalo K, Fuster MM. 2016. Functional importance of a proteoglycan coreceptor in pathologic lymphangiogenesis. Circ Res 119: 210-221.

Johnson NC, Dillard ME, Baluk P, McDonald DM, Harvey NL, Frase SL, Oliver G. 2008. Lymphatic endothelial cell identity is reversible and its maintenance requires Proxl activity. Genes Dev 22: 3282-3291.

Joukov V, Pajusola K, Kaipainen A, Chilov D, Lahtinen I, Kukk E, Saksela O, Kalkkinen N, Alitalo K. 1996. A novel vascular endothelial growth factor, VEGF-C, is a ligand for the Flt4 (VEGFR-3) and KDR (VEGFR-2) receptor tyrosine kinases. EMBO J 15: 290-298.

Joukov V, Sorsa T, Kumar V, Jeltsch M, Claesson-Welsh L, Cao Y, Saksela O, Kalkkinen N, Alitalo K. 1997. Proteolytic processing regulates receptor specificity and activity of VEGF-C. EMBO J 16: 3898-3911.

Kajiya K, Hirakawa S, Ma B, Drinnenberg I, Detmar M. 2005. Hepatocyte growth factor promotes lymphatic vessel formation and function. $E M B O J$ 24: 2885-2895.

Kaneko I, Tanaka S, Oka S, Kawamura T, Hiyama T, Ito M, Yoshihara M, Shimamoto F, Chayama K. 2007. Lymphatic vessel density at the site of deepest penetration as a predictor of lymph node metastasis in submucosal colorectal cancer. Dis Colon Rectum 50: 13-21.

Karalay O, Doberauer K, Vadodaria KC, Knobloch M, Berti L, Miquelajauregui A, Schwark M, Jagasia R, Taketo MM, Tarabykin V, et al. 2011. Prospero-related homeobox 1 gene (Prox1) is regulated by canonical Wnt signaling and has a stage-specific role in adult hippocampal neurogenesis. Proc Natl Acad Sci 108: $5807-5812$.

Karaman S, Detmar M. 2014. Mechanisms of lymphatic metastasis. J Clin Invest 124: 922-928.

Karkkainen MJ, Ferrell RE, Lawrence EC, Kimak MA, Levinson KL, McTigue MA, Alitalo K, Finegold DN. 2000. Missense mutations interfere with VEGFR-3 signalling in primary lymphoedema. Nat Genet 25: 153-159.

Karkkainen MJ, Saaristo A, Jussila L, Karila KA, Lawrence EC, Pajusola K, Bueler H, Eichmann A, Kauppinen R, Kettunen MI, et al. 2001. A model for gene therapy of human hereditary lymphedema. Proc Natl Acad Sci 98: 12677-12682.

Karkkainen MJ, Haiko P, Sainio K, Partanen J, Taipale J, Petrova TV, Jeltsch M, Jackson DG, Talikka M, Rauvala H, et al. 2004. Vascular endothelial growth factor $\mathrm{C}$ is required for sprouting 
of the first lymphatic vessels from embryonic veins. Nat Immunol 5: 74-80.

Karpanen T, Alitalo K. 2001. Lymphatic vessels as targets of tumor therapy? J Exp Med 194: F37-F42.

Karpanen T, Egeblad M, Karkkainen MJ, Kubo H, Yla-Herttuala S, Jaattela M, Alitalo K. 2001. Vascular endothelial growth factor $\mathrm{C}$ promotes tumor lymphangiogenesis and intralymphatic tumor growth. Cancer Res 61: 1786-1790.

Karpanen T, Padberg Y, van de Pavert SA, Dierkes C, Morooka N, Peterson-Maduro J, van de Hoek G, Adrian M, Mochizuki N, Sekiguchi K, et al. 2017. An evolutionarily conserved role for Polydom/Svep1 during lymphatic vessel formation. Circ Res 120: $1263-1275$.

Karpinich NO, Kechele DO, Espenschied ST, Willcockson HH, Fedoriw Y, Caron KM. 2013. Adrenomedullin gene dosage correlates with tumor and lymph node lymphangiogenesis. FASEB J 27: 590-600.

Kataru RP, Jung K, Jang C, Yang H, Schwendener RA, Baik JE, Han $\mathrm{SH}$, Alitalo K, Koh GY. 2009. Critical role of CD11 b ${ }^{+}$macrophages and VEGF in inflammatory lymphangiogenesis, antigen clearance, and inflammation resolution. Blood 113: 5650-5659.

Kataru RP, Kim H, Jang C, Choi DK, Koh BI, Kim M, Gollamudi S, Kim YK, Lee SH, Koh GY. 2011. T lymphocytes negatively regulate lymph node lymphatic vessel formation. Immunity 34: 96-107.

Kawamura H, Li X, Goishi K, van Meeteren LA, Jakobsson L, Cebe-Suarez S, Shimizu A, Edholm D, Ballmer-Hofer K, Kjellen L, et al. 2008. Neuropilin-1 in regulation of VEGF-induced activation of p38MAPK and endothelial cell organization. Blood 112: 3638-3649.

Kelley PM, Connor AL, Tempero RM. 2013. Lymphatic vessel memory stimulated by recurrent inflammation. Am I Pathol 182: $2418-2428$.

Kerjaschki D, Huttary N, Raab I, Regele H, Bojarski-Nagy K, Bartel G, Krober SM, Greinix H, Rosenmaier A, Karlhofer F, et al. 2006. Lymphatic endothelial progenitor cells contribute to de novo lymphangiogenesis in human renal transplants. Nat Med 12: 230-234.

Kim KE, Sung HK, Koh GY. 2007. Lymphatic development in mouse small intestine. Dev Dyn 236: 2020-2025.

Kim KE, Koh YJ, Jeon BH, Jang C, Han J, Kataru RP, Schwendener RA, Kim JM, Koh GY. 2009. Role of CD1 $\mathrm{bb}^{+}$macrophages in intraperitoneal lipopolysaccharide-induced aberrant lymphangiogenesis and lymphatic function in the diaphragm. Am J Pathol 175: 1733-1745.

Kim H, Kataru RP, Koh GY. 2014. Inflammation-associated lymphangiogenesis: a double-edged sword? J Clin Invest 124: 936-942.

Kim S, Chung M, Jeon NL. 2016. Three-dimensional biomimetic model to reconstitute sprouting lymphangiogenesis in vitro. Biomaterials 78: 115-128.

Kirilovsky A, Marliot F, El Sissy C, Haicheur N, Galon J, Pages F. 2016. Rational bases for the use of the Immunoscore in routine clinical settings as a prognostic and predictive biomarker in cancer patients. Int Immunol 28: 373-382.

Kizhatil K, Ryan M, Marchant JK, Henrich S, John SW. 2014. Schlemm's canal is a unique vessel with a combination of blood vascular and lymphatic phenotypes that forms by a novel developmental process. PLOS Biol 12: e1001912.

Klein KR, Karpinich NO, Espenschied ST, Willcockson HH, Dunworth WP, Hoopes SL, Kushner EJ, Bautch VL, Caron KM. 2014. Decoy receptor CXCR7 modulates adrenomedullin-mediated cardiac and lymphatic vascular development. Dev Cell 30: $528-540$.
Klotz L, Norman S, Vieira JM, Masters M, Rohling M, Dube KN, Bollini S, Matsuzaki F, Carr CA, Riley PR. 2015. Cardiac lymphatics are heterogeneous in origin and respond to injury. $\mathrm{Na}$ ture 522: 62-67.

Kojima T, Azar DT, Chang JH. 2008. Neostatin-7 regulates bFGF-induced corneal lymphangiogenesis. FEBS Lett 582: 2515-2520.

Koltowska K, Betterman KL, Harvey NL, Hogan BM. 2013. Getting out and about: the emergence and morphogenesis of the vertebrate lymphatic vasculature. Development 140: 1857-1870.

Koltowska K, Lagendijk AK, Pichol-Thievend C, Fischer JC, Francois M, Ober EA, Yap AS, Hogan BM. 2015. Vegfc regulates bipotential precursor division and Proxl expression to promote lymphatic identity in zebrafish. Cell Rep 13: 1828-1841.

Korn C, Augustin HG. 2015. Mechanisms of vessel pruning and regression. Dev Cell 34: 5-17.

Krishnan J, Kirkin V, Steffen A, Hegen M, Weih D, Tomarev S, Wilting J, Sleeman JP. 2003. Differential in vivo and in vitro expression of vascular endothelial growth factor (VEGF)-C and VEGF-D in tumors and its relationship to lymphatic metastasis in immunocompetent rats. Cancer Res 63: 713-722.

Kubo H, Cao R, Brakenhielm E, Makinen T, Cao Y, Alitalo K. 2002. Blockade of vascular endothelial growth factor receptor-3 signaling inhibits fibroblast growth factor-2-induced lymphangiogenesis in mouse cornea. Proc Natl Acad Sci 99: 8868-8873.

Kubota Y, Takubo K, Shimizu T, Ohno H, Kishi K, Shibuya M, Saya H, Suda T. 2009. M-CSF inhibition selectively targets pathological angiogenesis and lymphangiogenesis. J Exp Med 206: 1089-1102.

Kunstfeld R, Hirakawa S, Hong YK, Schacht V, Lange-Asschenfeldt B, Velasco P, Lin C, Fiebiger E, Wei X, Wu Y, et al. 2004. Induction of cutaneous delayed-type hypersensitivity reactions in VEGF-A transgenic mice results in chronic skin inflammation associated with persistent lymphatic hyperplasia. Blood 104: 1048-1057.

Kwon HB, Fukuhara S, Asakawa K, Ando K, Kashiwada T, Kawakami K, Hibi M, Kwon YG, Kim KW, Alitalo K, et al. 2013. The parallel growth of motoneuron axons with the dorsal aorta depends on Vegfc/Vegfr3 signaling in zebrafish. Development 140: 4081-4090.

Leak LV, Burke JF. 1968. Ultrastructural studies on the lymphatic anchoring filaments. J Cell Biol 36: 129-149.

Lee JY, Park C, Cho YP, Lee E, Kim H, Kim P, Yun SH, Yoon YS. 2010. Podoplanin-expressing cells derived from bone marrow play a crucial role in postnatal lymphatic neovascularization. Circulation 122: 1413-1425.

Lee KM, Danuser R, Stein JV, Graham D, Nibbs RJ, Graham GJ. 2014. The chemokine receptors ACKR2 and CCR2 reciprocally regulate lymphatic vessel density. EMBO J 33: 2564-2580.

Lee S, Rho SS, Park H, Park JA, Kim J, Lee IK, Koh GY, Mochizuki N, Kim YM, Kwon YG. 2017. Carbohydrate-binding protein CLEC14A regulates VEGFR-2- and VEGFR-3-dependent signals during angiogenesis and lymphangiogenesis. J Clin Invest 127: 457-471.

Le Guen L, Karpanen T, Schulte D, Harris NC, Koltowska K, Roukens G, Bower NI, van Impel A, Stacker SA, Achen MG, et al. 2014. Ccbe1 regulates Vegfc-mediated induction of Vegfr3 signaling during embryonic lymphangiogenesis. Development 141: 1239-1249.

Li J, Hou B, Tumova S, Muraki K, Bruns A, Ludlow MJ, Sedo A, Hyman AJ, McKeown L, Young RS, et al. 2014. Piezol integration of vascular architecture with physiological force. Nature 515: 279-282. 
Liao YF, Gotwals PJ, Koteliansky VE, Sheppard D, Van De Water L. 2002. The EIIIA segment of fibronectin is a ligand for integrins $\alpha 9 \beta 1$ and $\alpha 4 \beta 1$ providing a novel mechanism for regulating cell adhesion by alternative splicing. I Biol Chem 277: 14467-14474.

Lim AH, Suli A, Yaniv K, Weinstein B, Li DY, Chien CB. 2011. Motoneurons are essential for vascular pathfinding. Development 138: 3847-3857.

Lin J, Lalani AS, Harding TC, Gonzalez M, Wu WW, Luan B, Tu GH, Koprivnikar K, VanRoey MJ, He Y, et al. 2005. Inhibition of lymphogenous metastasis using adeno-associated virusmediated gene transfer of a soluble VEGFR-3 decoy receptor. Cancer Res 65: 6901-6909.

Lin FJ, Chen X, Qin J, Hong YK, Tsai MJ, Tsai SY. 2010. Direct transcriptional regulation of neuropilin-2 by COUP-TFII modulates multiple steps in murine lymphatic vessel development. J Clin Invest 120: 1694-1707.

Liu X, Pasula S, Song H, Tessneer KL, Dong Y, Hahn S, Yago T, Brophy ML, Chang B, Cai X, et al. 2014. Temporal and spatial regulation of epsin abundance and VEGFR3 signaling are required for lymphatic valve formation and function. Sci Signal 7: ra97.

Liu X, Uemura A, Fukushima Y, Yoshida Y, Hirashima M. 2016. Semaphorin $3 \mathrm{G}$ provides a repulsive guidance cue to lymphatic endothelial cells via Neuropilin-2/PlexinD1. Cell Rep 17: 2299-2311.

Lobov IB, Renard RA, Papadopoulos N, Gale NW, Thurston G, Yancopoulos GD, Wiegand SJ. 2007. Delta-like ligand 4 (D1l4) is induced by VEGF as a negative regulator of angiogenic sprouting. Proc Natl Acad Sci 104: 3219-3224.

Louveau A, Smirnov I, Keyes TJ, Eccles JD, Rouhani SJ, Peske JD, Derecki NC, Castle D, Mandell JW, Lee KS, et al. 2015. Structural and functional features of central nervous system lymphatic vessels. Nature 523: 337-341.

Lukacs V, Mathur J, Mao R, Bayrak-Toydemir P, Procter M, Cahalan SM, Kim HJ, Bandell M, Longo N, Day RW, et al. 2015. Impaired PIEZO1 function in patients with a novel autosomal recessive congenital lymphatic dysplasia. Nat Commun 6: 8329.

Lutter S, Xie S, Tatin F, Makinen T. 2012. Smooth muscle-endothelial cell communication activates Reelin signaling and regulates lymphatic vessel formation. J Cell Biol 197: 837-849.

Ma GC, Liu CS, Chang SP, Yeh KT, Ke YY, Chen TH, Wang BB, Kuo SJ, Shih JC, Chen M. 2008. A recurrent ITGA9 missense mutation in human fetuses with severe chylothorax: possible correlation with poor response to fetal therapy. Prenat Diagn 28: $1057-1063$.

Machnik A, Neuhofer W, Jantsch J, Dahlmann A, Tammela T, Machura K, Park JK, Beck FX, Muller DN, Derer W, et al. 2009. Macrophages regulate salt-dependent volume and blood pressure by a vascular endothelial growth factor-C-dependent buffering mechanism. Nat Med 15: 545-552.

Mahadevan A, Welsh IC, Sivakumar A, Gludish DW, Shilvock AR, Noden DM, Huss D, Lansford R, Kurpios NA. 2014. The left-right Pitx2 pathway drives organ-specific arterial and lymphatic development in the intestine. Dev Cell 31: 690-706.

Makinen T, Jussila L, Veikkola T, Karpanen T, Kettunen MI, Pulkkanen KJ, Kauppinen R, Jackson DG, Kubo H, Nishikawa $\mathrm{S}$, et al. 2001. Inhibition of lymphangiogenesis with resulting lymphedema in transgenic mice expressing soluble VEGF receptor-3. Nat Med 7: 199-205.

Makinen T, Adams RH, Bailey J, Lu Q, Ziemiecki A, Alitalo K, Klein R, Wilkinson GA. 2005. PDZ interaction site in eph-
rinB2 is required for the remodeling of lymphatic vasculature. Genes Dev 19: 397-410.

Mandriota SJ, Jussila L, Jeltsch M, Compagni A, Baetens D, Prevo R, Banerji S, Huarte J, Montesano R, Jackson DG, et al. 2001. Vascular endothelial growth factor-C-mediated lymphangiogenesis promotes tumour metastasis. EMBO J 20: 672-682.

Marino D, Angehrn Y, Klein S, Riccardi S, Baenziger-Tobler N, Otto VI, Pittelkow M, Detmar M. 2013. Activation of the epidermal growth factor receptor promotes lymphangiogenesis in the skin. J Dermatol Sci 71: 184-194.

Martinez-Corral I, Makinen T. 2013. Regulation of lymphatic vascular morphogenesis: implications for pathological (tumor) lymphangiogenesis. Exp Cell Res 319: 1618-1625.

Martinez-Corral I, Ulvmar MH, Stanczuk L, Tatin F, Kizhatil K, John SW, Alitalo K, Ortega S, Makinen T. 2015. Nonvenous origin of dermal lymphatic vasculature. Circ Res 116: 1649-1654.

Maruyama K, Ii M, Cursiefen C, Jackson DG, Keino H, Tomita M, Van Rooijen N, Takenaka H, D'Amore PA, Stein-Streilein J, et al. 2005. Inflammation-induced lymphangiogenesis in the cornea arises from CD1 1b-positive macrophages. J Clin Invest 115: 2363-2372.

Matsui K, Nagy-Bojarsky K, Laakkonen P, Krieger S, Mechtler K, Uchida S, Geleff S, Kang DH, Johnson RJ, Kerjaschki D. 2003. Lymphatic microvessels in the rat remnant kidney model of renal fibrosis: aminopeptidase $\mathrm{p}$ and podoplanin are discriminatory markers for endothelial cells of blood and lymphatic vessels. J Am Soc Nephrol 14: 1981-1989.

Matsumoto K, Nakayama Y, Inoue Y, Minagawa N, Katsuki T, Shibao K, Tsurudome Y, Hirata K, Nagata N, Itoh H. 2007. Lymphatic microvessel density is an independent prognostic factor in colorectal cancer. Dis Colon Rectum 50: 308-314.

Mishima K, Watabe T, Saito A, Yoshimatsu Y, Imaizumi N, Masui S, Hirashima M, Morisada T, Oike Y, Araie M, et al. 2007. Prox1 induces lymphatic endothelial differentiation via integrin $\alpha 9$ and other signaling cascades. Mol Biol Cell 18: $1421-1429$.

Mlecnik B, Bindea G, Kirilovsky A, Angell HK, Obenauf AC, Tosolini M, Church SE, Maby P, Vasaturo A, Angelova M, et al. 2016. The tumor microenvironment and Immunoscore are critical determinants of dissemination to distant metastasis. Sci Transl Med 8: 327ra326.

Moertel CG, Fleming TR, Macdonald JS, Haller DG, Laurie JA, Tangen CM, Ungerleider JS, Emerson WA, Tormey DC, Glick $\mathrm{JH}$, et al. 1995. Fluorouracil plus levamisole as effective adjuvant therapy after resection of stage III colon carcinoma: a final report. Ann Intern Med 122: 321-326.

Morisada T, Oike Y, Yamada Y, Urano T, Akao M, Kubota Y, Maekawa H, Kimura Y, Ohmura M, Miyamoto T, et al. 2005. Angiopoietin-1 promotes LYVE-1-positive lymphatic vessel formation. Blood 105: 4649-4656.

Morooka N, Futaki S, Sato-Nishiuchi R, Nishino M, Totani Y, Shimono C, Nakano I, Nakajima H, Mochizuki N, Sekiguchi K. 2017. Polydom is an extracellular matrix protein involved in lymphatic vessel remodeling. Circ Res 120: 1276-1288.

Mukouyama YS, Shin D, Britsch S, Taniguchi M, Anderson DJ. 2002. Sensory nerves determine the pattern of arterial differentiation and blood vessel branching in the skin. Cell 109: 693-705.

Mumblat Y, Kessler O, Ilan N, Neufeld G. 2015. Full-length semaphorin-3C is an inhibitor of tumor lymphangiogenesis and metastasis. Cancer Res 75: 2177-2186.

Mumprecht V, Detmar M. 2013. In vivo imaging of lymph node lymphangiogenesis by immuno-positron emission tomography. Methods Mol Biol 961: 129-140. 
Murtomaki A, Uh MK, Choi YK, Kitajewski C, Borisenko V, Kitajewski J, Shawber CJ. 2013. Notch1 functions as a negative regulator of lymphatic endothelial cell differentiation in the venous endothelium. Development 140: 2365-2376.

Nagy JA, Vasile E, Feng D, Sundberg C, Brown LF, Detmar MJ, Lawitts JA, Benjamin L, Tan X, Manseau EJ, et al. 2002. Vascular permeability factor/vascular endothelial growth factor induces lymphangiogenesis as well as angiogenesis. I Exp Med 196: $1497-1506$.

Nakamura Y, Yasuoka H, Tsujimoto M, Imabun S, Nakahara M, Nakao K, Nakamura M, Mori I, Kakudo K. 2005. Lymph vessel density correlates with nodal status, VEGF-C expression, and prognosis in breast cancer. Breast Cancer Res Treat 91: $125-132$.

Naxerova K, Reiter JG, Brachtel E, Lennerz JK, van de Wetering M, Rowan A, Cai T, Clevers H, Swanton C, Nowak MA, et al. 2017. Origins of lymphatic and distant metastases in human colorectal cancer. Science 357: 55-60.

$\mathrm{Ng}$ CP, Helm CL, Swartz MA. 2004. Interstitial flow differentially stimulates blood and lymphatic endothelial cell morphogenesis in vitro. Microvasc Res 68: 258-264.

Nicenboim J, Malkinson G, Lupo T, Asaf L, Sela Y, Mayseless O, Gibbs-Bar L, Senderovich N, Hashimshony T, Shin M, et al. 2015. Lymphatic vessels arise from specialized angioblasts within a venous niche. Nature 522: 56-61.

Niessen K, Zhang G, Ridgway JB, Chen H, Kolumam G, Siebel CW, Yan M. 2011. The Notch1-Dll4 signaling pathway regulates mouse postnatal lymphatic development. Blood 118: 1989-1997.

Nurmi H, Saharinen P, Zarkada G, Zheng W, Robciuc MR, Alitalo K. 2015. VEGF-C is required for intestinal lymphatic vessel maintenance and lipid absorption. EMBO Mol Med 7: $1418-1425$.

Nykanen AI, Sandelin H, Krebs R, Keranen MA, Tuuminen R, Karpanen T, Wu Y, Pytowski B, Koskinen PK, Yla-Herttuala $\mathrm{S}$, et al. 2010. Targeting lymphatic vessel activation and CCL21 production by vascular endothelial growth factor receptor-3 inhibition has novel immunomodulatory and antiarteriosclerotic effects in cardiac allografts. Circulation 121: 1413-1422.

Ochoa-Espinosa A, Affolter M. 2012. Branching morphogenesis: from cells to organs and back. Cold Spring Harb Perspect Biol 4: a008243.

Ochsenbein AM, Karaman S, Proulx ST, Goldmann R, Chittazhathu J, Dasargyri A, Chong C, Leroux JC, Stanley ER, Detmar M. 2016. Regulation of lymphangiogenesis in the diaphragm by macrophages and VEGFR-3 signaling. Angiogenesis 19: 513-524.

Oh SJ, Jeltsch MM, Birkenhager R, McCarthy JE, Weich HA, Christ B, Alitalo K, Wilting J. 1997. VEGF and VEGF-C: specific induction of angiogenesis and lymphangiogenesis in the differentiated avian chorioallantoic membrane. Dev Biol 188: 96-109.

Oka M, Iwata C, Suzuki HI, Kiyono K, Morishita Y, Watabe T, Komuro A, Kano MR, Miyazono K. 2008. Inhibition of endogenous TGF- $\beta$ signaling enhances lymphangiogenesis. Blood 111: 4571-4579.

Okazaki T, Ni A, Ayeni OA, Baluk P, Yao LC, Vossmeyer D, Zischinsky G, Zahn G, Knolle J, Christner C, et al. 2009. a5 $\beta 1$ integrin blockade inhibits lymphangiogenesis in airway inflammation. Am J Pathol 174: 2378-2387.

Osawa M, Masuda M, Kusano K, Fujiwara K. 2002. Evidence for a role of platelet endothelial cell adhesion molecule- 1 in endothelial cell mechanosignal transduction: is it a mechanoresponsive molecule? J Cell Biol 158: 773-785.
Ou JJ, Wu F, Liang HJ. 2010. Colorectal tumor derived fibronectin alternatively spliced EDA domain exserts lymphangiogenic effect on human lymphatic endothelial cells. Cancer Biol Ther 9: 186-191.

Ou J, Li J, Pan F, Xie G, Zhou Q, Huang H, Liang H. 2011. Endostatin suppresses colorectal tumor-induced lymphangiogenesis by inhibiting expression of fibronectin extra domain A and integrin a9. J Cell Biochem 112: 2106-2114.

Outeda P, Huso DL, Fisher SA, Halushka MK, Kim H, Qian F, Germino GG, Watnick T. 2014. Polycystin signaling is required for directed endothelial cell migration and lymphatic development. Cell Rep 7: 634-644.

Paquet-Fifield S, Levy SM, Sato T, Shayan R, Karnezis T, Davydova N, Nowell CI, Roufail S, Ma GZ, Zhang YF, et al. 2013. Vascular endothelial growth factor-d modulates caliber and function of initial lymphatics in the dermis. J Invest Dermatol 133: 2074-2084.

Partanen TA, Arola J, Saaristo A, Jussila L, Ora A, Miettinen M, Stacker SA, Achen MG, Alitalo K. 2000. VEGF-C and VEGF$\mathrm{D}$ expression in neuroendocrine cells and their receptor, VEGFR-3, in fenestrated blood vessels in human tissues. FASEB J 14: 2087-2096.

Paupert J, Sounni NE, Noel A. 2011. Lymphangiogenesis in postnatal tissue remodeling: lymphatic endothelial cell connection with its environment. Mol Aspects Med 32: 146-158.

Pavlov V, Rosental B, Hansen NF, Beers JM, Parish G, Rowbotham I, Block BA. 2017. Hydraulic control of tuna fins: a role for the lymphatic system in vertebrate locomotion. Science 357: 310-314.

Petrova TV, Makinen T, Makela TP, Saarela J, Virtanen I, Ferrell RE, Finegold DN, Kerjaschki D, Yla-Herttuala S, Alitalo K. 2002. Lymphatic endothelial reprogramming of vascular endothelial cells by the Prox-1 homeobox transcription factor. EMBO I 21: 4593-4599.

Petrova TV, Nykanen A, Norrmen C, Ivanov KI, Andersson LC, Haglund C, Puolakkainen P, Wempe F, von Melchner H, Gradwohl G, et al. 2008. Transcription factor PROX1 induces colon cancer progression by promoting the transition from benign to highly dysplastic phenotype. Cancer Cell 13: 407-419.

Pflicke H, Sixt M. 2009. Preformed portals facilitate dendritic cell entry into afferent lymphatic vessels. I Exp Med 206: 2925-2935.

Pitulescu ME, Schmidt I, Giaimo BD, Antoine T, Berkenfeld F, Ferrante F, Park H, Ehling M, Biljes D, Rocha SF, et al. 2017. Dll4 and Notch signalling couples sprouting angiogenesis and artery formation. Nat Cell Biol 19: 915-927.

Planas-Paz L, Strilic B, Goedecke A, Breier G, Fassler R, Lammert E. 2012. Mechanoinduction of lymph vessel expansion. EMBO J 31: 788-804.

Ranade SS, Qiu Z, Woo SH, Hur SS, Murthy SE, Cahalan SM, Xu J, Mathur J, Bandell M, Coste B, et al. 2014. Piezo1, a mechanically activated ion channel, is required for vascular development in mice. Proc Natl Acad Sci 111: 10347-10352.

Religa P, Cao R, Bjorndahl M, Zhou Z, Zhu Z, Cao Y. 2005. Presence of bone marrow-derived circulating progenitor endothelial cells in the newly formed lymphatic vessels. Blood 106: 4184-4190.

Renyi-Vamos F, Tovari J, Fillinger J, Timar J, Paku S, Kenessey I, Ostoros G, Agocs L, Soltesz I, Dome B. 2005. Lymphangiogenesis correlates with lymph node metastasis, prognosis, and angiogenic phenotype in human non-small cell lung cancer. Clin Cancer Res 11: 7344-7353.

Roberts N, Kloos B, Cassella M, Podgrabinska S, Persaud K, Wu Y, Pytowski B, Skobe M. 2006. Inhibition of VEGFR-3 activation with the antagonistic antibody more potently suppresses 
lymph node and distant metastases than inactivation of VEGFR-2. Cancer Res 66: 2650-2657.

Ruhrberg C, Gerhardt H, Golding M, Watson R, Ioannidou S, Fujisawa H, Betsholtz C, Shima DT. 2002. Spatially restricted patterning cues provided by heparin-binding VEGF-A control blood vessel branching morphogenesis. Genes Dev 16: 2684-2698.

Rutkowski JM, Boardman KC, Swartz MA. 2006. Characterization of lymphangiogenesis in a model of adult skin regeneration. Am J Physiol Heart Circ Physiol 291: H1402-H1410.

Saad RS, Kordunsky L, Liu YL, Denning KL, Kandil HA, Silverman JF. 2006. Lymphatic microvessel density as prognostic marker in colorectal cancer. Mod Pathol 19: 1317-1323.

Sabin FR. 1902. On the origin of the lymphatic system from the veins, and the development of the lymph hearts and thoracic duct in the pig. Am J Anat 1: 367-389.

Sabine A, Agalarov Y, Maby-El Hajjami H, Jaquet M, Hagerling R, Pollmann C, Bebber D, Pfenniger A, Miura N, Dormond O, et al. 2012. Mechanotransduction, PROX1, and FOXC2 cooperate to control connexin37 and calcineurin during lymphatic-valve formation. Dev Cell 22: 430-445.

Saharinen P, Helotera H, Miettinen J, Norrmen C, D'Amico G, Jeltsch M, Langenberg T, Vandevelde W, Ny A, Dewerchin $M$, et al. 2010. Claudin-like protein 24 interacts with the VEGFR-2 and VEGFR-3 pathways and regulates lymphatic vessel development. Genes Dev 24: 875-880.

Sainson RC, Aoto J, Nakatsu MN, Holderfield M, Conn E, Koller E, Hughes CC. 2005. Cell-autonomous notch signaling regulates endothelial cell branching and proliferation during vascular tubulogenesis. FASEB J 19: 1027-1029.

Salven P, Lymboussaki A, Heikkila P, Jaaskela-Saari H, Enholm B, Aase K, von Euler G, Eriksson U, Alitalo K, Joensuu H. 1998. Vascular endothelial growth factors VEGF-B and VEGF-C are expressed in human tumors. Am J Pathol 153: 103-108.

Sauter B, Foedinger D, Sterniczky B, Wolff K, Rappersberger K. 1998. Immunoelectron microscopic characterization of human dermal lymphatic microvascular endothelial cells. Differential expression of CD31, CD34, and type IV collagen with lymphatic endothelial cells vs blood capillary endothelial cells in normal human skin, lymphangioma, and hemangioma in situ. J Histochem Cytochem 46: 165-176.

Sawamiphak S, Seidel S, Essmann CL, Wilkinson GA, Pitulescu ME, Acker T, Acker-Palmer A. 2010. Ephrin-B2 regulates VEGFR2 function in developmental and tumour angiogenesis. Nature 465: 487-491.

Schacht V, Ramirez MI, Hong YK, Hirakawa S, Feng D, Harvey N, Williams M, Dvorak AM, Dvorak HF, Oliver G, et al. 2003. $\mathrm{T} 1 \alpha /$ podoplanin deficiency disrupts normal lymphatic vasculature formation and causes lymphedema. EMBO $J$ 22: 3546-3556.

Schoppmann SF, Birner P, Stockl J, Kalt R, Ullrich R, Caucig C, Kriehuber E, Nagy K, Alitalo K, Kerjaschki D. 2002. Tumorassociated macrophages express lymphatic endothelial growth factors and are related to peritumoral lymphangiogenesis. Am J Pathol 161: 947-956.

Schulte-Merker S, Sabine A, Petrova TV. 2011. Lymphatic vascular morphogenesis in development, physiology, and disease. $J$ Cell Biol 193: 607-618.

Secker GA, Harvey NL. 2015. VEGFR signaling during lymphatic vascular development: from progenitor cells to functional vessels. Dev Dyn 244: 323-331.

Siegfried G, Basak A, Cromlish JA, Benjannet S, Marcinkiewicz J, Chretien M, Seidah NG, Khatib AM. 2003. The secretory pro- protein convertases furin, PC5, and PC7 activate VEGF-C to induce tumorigenesis. J Clin Invest 111: 1723-1732.

Siekmann AF, Lawson ND. 2007. Notch signalling limits angiogenic cell behaviour in developing zebrafish arteries. Nature 445: 781-784.

Skobe M, Brown LF, Tognazzi K, Ganju RK, Dezube BJ, Alitalo K, Detmar M. 1999. Vascular endothelial growth factor-C (VEGF-C) and its receptors KDR and flt-4 are expressed in AIDS-associated Kaposi's sarcoma. I Invest Dermatol 113: 1047-1053.

Skobe M, Hawighorst T, Jackson DG, Prevo R, Janes L, Velasco P, Riccardi L, Alitalo K, Claffey K, Detmar M. 2001. Induction of tumor lymphangiogenesis by VEGF-C promotes breast cancer metastasis. Nat Med 7: 192-198.

Srinivasan RS, Dillard ME, Lagutin OV, Lin FJ, Tsai S, Tsai MJ, Samokhvalov IM, Oliver G. 2007. Lineage tracing demonstrates the venous origin of the mammalian lymphatic vasculature. Genes Dev 21: 2422-2432.

Srinivasan RS, Geng X, Yang Y, Wang Y, Mukatira S, Studer M, Porto MP, Lagutin O, Oliver G. 2010. The nuclear hormone receptor Coup-TFII is required for the initiation and early maintenance of Prox1 expression in lymphatic endothelial cells. Genes Dev 24: 696-707.

Stacker SA, Caesar C, Baldwin ME, Thornton GE, Williams RA, Prevo R, Jackson DG, Nishikawa S, Kubo H, Achen MG. 2001. VEGF-D promotes the metastatic spread of tumor cells via the lymphatics. Nat Med 7: 186-191.

Stacker SA, Williams SP, Karnezis T, Shayan R, Fox SB, Achen MG. 2014. Lymphangiogenesis and lymphatic vessel remodelling in cancer. Nat Rev Cancer 14: 159-172.

Stanczuk L, Martinez-Corral I, Ulvmar MH, Zhang Y, Lavina B, Fruttiger M, Adams RH, Saur D, Betsholtz C, Ortega S, et al. 2015. cKit lineage hemogenic endothelium-derived cells contribute to mesenteric lymphatic vessels. Cell Rep 10: 1708-1721.

Stenzel D, Franco CA, Estrach S, Mettouchi A, Sauvaget D, Rosewell I, Schertel A, Armer H, Domogatskaya A, Rodin S, et al. 2011. Endothelial basement membrane limits tip cell formation by inducing Dll4/Notch signalling in vivo. EMBO Rep 12: 1135-1143.

Stone J, Itin A, Alon T, Pe'er J, Gnessin H, Chan-Ling T, Keshet E. 1995. Development of retinal vasculature is mediated by hypoxia-induced vascular endothelial growth factor (VEGF) expression by neuroglia. J Neurosci 15: 4738-4747.

Suchting S, Freitas C, le Noble F, Benedito R, Breant C, Duarte A, Eichmann A. 2007. The Notch ligand Delta-like 4 negatively regulates endothelial tip cell formation and vessel branching. Proc Natl Acad Sci 104: 3225-3230.

Sutherland D, Samakovlis C, Krasnow MA. 1996. branchless encodes a Drosophila FGF homolog that controls tracheal cell migration and the pattern of branching. Cell 87: 1091-1101.

Takanami I. 2006. Lymphatic microvessel density using D2-40 is associated with nodal metastasis in non-small cell lung cancer. Oncol Rep 15: 437-442.

Tammela T, Saaristo A, Lohela M, Morisada T, Tornberg J, Norrmen C, Oike Y, Pajusola K, Thurston G, Suda T, et al. 2005. Angiopoietin-1 promotes lymphatic sprouting and hyperplasia. Blood 105: 4642-4648.

Tammela T, He Y, Lyytikka J, Jeltsch M, Markkanen J, Pajusola K, Yla-Herttuala S, Alitalo K. 2007. Distinct architecture of lymphatic vessels induced by chimeric vascular endothelial growth factor-C/vascular endothelial growth factor heparinbinding domain fusion proteins. Circ Res 100: 1468-1475.

Tammela T, Zarkada G, Wallgard E, Murtomaki A, Suchting S, Wirzenius M, Waltari M, Hellstrom M, Schomber T, Peltonen 
$\mathrm{R}$, et al. 2008. Blocking VEGFR-3 suppresses angiogenic sprouting and vascular network formation. Nature 454: 656-660.

Tobler NE, Detmar M. 2006. Tumor and lymph node lymphangiogenesis-impact on cancer metastasis. I Leukoc Biol 80: 691-696.

Tzima E, Irani-Tehrani M, Kiosses WB, Dejana E, Schultz DA, Engelhardt B, Cao G, DeLisser H, Schwartz MA. 2005. A mechanosensory complex that mediates the endothelial cell response to fluid shear stress. Nature 437: 426-431.

Ubezio B, Blanco RA, Geudens I, Stanchi F, Mathivet T, Jones ML, Ragab A, Bentley K, Gerhardt H. 2016. Synchronization of endothelial Dll4-Notch dynamics switch blood vessels from branching to expansion. Elife 5: e12167.

Uchida Y, James JM, Suto F, Mukouyama YS. 2015. Class 3 semaphorins negatively regulate dermal lymphatic network formation. Biol Open 4: 1194-1205.

Ulvmar MH, Makinen T. 2016. Heterogeneity in the lymphatic vascular system and its origin. Cardiovasc Res 111: 310-321.

Vainionpaa N, Butzow R, Hukkanen M, Jackson DG, Pihlajaniemi T, Sakai LY, Virtanen I. 2007. Basement membrane protein distribution in LYVE-1-immunoreactive lymphatic vessels of normal tissues and ovarian carcinomas. Cell Tissue Res 328: 317-328.

Valtola R, Salven P, Heikkila P, Taipale J, Joensuu H, Rehn M, Pihlajaniemi T, Weich H, deWaal R, Alitalo K. 1999. VEGFR-3 and its ligand VEGF-C are associated with angiogenesis in breast cancer. Am J Pathol 154: 1381-1390.

van Lessen M, Shibata-Germanos S, van Impel A, Hawkins TA, Rihel J, Schulte-Merker S. 2017. Intracellular uptake of macromolecules by brain lymphatic endothelial cells during zebrafish embryonic development. Elife 6: e25932.

Venero Galanternik M, Castranova D, Gore AV, Blewett $\mathrm{NH}$, Jung HM, Stratman AN, Kirby MR, Iben J, Miller MF, Kawakami K, et al. 2017. A novel perivascular cell population in the zebrafish brain. Elife 6: e25932.

Wang JF, Zhang XF, Groopman JE. 2001. Stimulation of $\beta 1$ integrin induces tyrosine phosphorylation of vascular endothelial growth factor receptor-3 and modulates cell migration. I Biol Chem 276: 41950-41957.

Wang Y, Nakayama M, Pitulescu ME, Schmidt TS, Bochenek ML, Sakakibara A, Adams S, Davy A, Deutsch U, Luthi U, et al. 2010. Ephrin-B2 controls VEGF-induced angiogenesis and lymphangiogenesis. Nature 465: 483-486.

Wang Y, Baeyens N, Corti F, Tanaka K, Fang JS, Zhang J, Jin Y, Coon B, Hirschi KK, Schwartz MA, et al. 2016. Syndecan-4 controls lymphatic vasculature remodeling during embryonic development. Development 143: 4441-4451.

Wigle JT, Oliver G. 1999. Prox 1 function is required for the development of the murine lymphatic system. Cell 98: 769-778.

Wigle JT, Harvey N, Detmar M, Lagutina I, Grosveld G, Gunn MD, Jackson DG, Oliver G. 2002. An essential role for Prox1 in the induction of the lymphatic endothelial cell phenotype. EMBO I 21: 1505-1513.

Wirzenius $M$, Tammela $\mathrm{T}$, Uutela $\mathrm{M}, \mathrm{He} \mathrm{Y}$, Odorisio $\mathrm{T}$, Zambruno G, Nagy JA, Dvorak HF, Yla-Herttuala S, Shibuya M, et al. 2007. Distinct vascular endothelial growth factor signals for lymphatic vessel enlargement and sprouting. I Exp Med 204: 1431-1440.

Wong HL, Jin G, Cao R, Zhang S, Cao Y, Zhou Z. 2016. MT1MMP sheds LYVE-1 on lymphatic endothelial cells and suppresses VEGF-C production to inhibit lymphangiogenesis. Nat Commun 7: 10824.
Xu Y, Yuan L, Mak J, Pardanaud L, Caunt M, Kasman I, Larrivee B, Del Toro R, Suchting S, Medvinsky A, et al. 2010. Neuropilin-2 mediates VEGF-C-induced lymphatic sprouting together with VEGFR3. J Cell Biol 188: 115-130.

Yang Y, Garcia-Verdugo JM, Soriano-Navarro M, Srinivasan RS, Scallan JP, Singh MK, Epstein JA, Oliver G. 2012. Lymphatic endothelial progenitors bud from the cardinal vein and intersomitic vessels in mammalian embryos. Blood 120: 2340-2348.

Yaniv K, Isogai S, Castranova D, Dye L, Hitomi J, Weinstein BM. 2006. Live imaging of lymphatic development in the zebrafish. Nat Med 12: 711-716.

Yao LC, Baluk P, Srinivasan RS, Oliver G, McDonald DM. 2012. Plasticity of button-like junctions in the endothelium of airway lymphatics in development and inflammation. Am I Pathol 180: 2561-2575.

Yin X, Johns SC, Lawrence R, Xu D, Reddi K, Bishop JR, Varner JA, Fuster MM. 2011. Lymphatic endothelial heparan sulfate deficiency results in altered growth responses to vascular endothelial growth factor-C (VEGF-C). I Biol Chem 286: 14952-14962.

Yu P, Wilhelm K, Dubrac A, Tung JK, Alves TC, Fang JS, Xie Y, Zhu J, Chen Z, De Smet F, et al. 2017. FGF-dependent metabolic control of vascular development. Nature 545: 224-228.

Yuan L, Moyon D, Pardanaud L, Breant C, Karkkainen MJ, Alitalo K, Eichmann A. 2002. Abnormal lymphatic vessel development in neuropilin 2 mutant mice. Development 129: 4797-4806.

Zampell JC, Avraham T, Yoder N, Fort N, Yan A, Weitman ES, Mehrara BJ. 2012. Lymphatic function is regulated by a coordinated expression of lymphangiogenic and anti-lymphangiogenic cytokines. Am I Physiol Cell Physiol 302: C392C404.

Zarkada G, Heinolainen K, Makinen T, Kubota Y, Alitalo K. 2015. VEGFR3 does not sustain retinal angiogenesis without VEGFR2. Proc Nat1 Acad Sci 112: 761-766.

Zhang X, Groopman JE, Wang JF. 2005. Extracellular matrix regulates endothelial functions through interaction of VEGFR-3 and integrin $\alpha 5 \beta 1$. J Cell Physiol 202: 205-214.

Zhang N, Schroppel B, Lal G, Jakubzick C, Mao X, Chen D, Yin N, Jessberger R, Ochando JC, Ding Y, et al. 2009. Regulatory T cells sequentially migrate from inflamed tissues to draining lymph nodes to suppress the alloimmune response. Immunity 30: 458-469.

Zhang L, Zhou F, Han W, Shen B, Luo J, Shibuya M, He Y. 2010. VEGFR-3 ligand-binding and kinase activity are required for lymphangiogenesis but not for angiogenesis. Cell Res 20: 1319-1331.

Zheng W, Tammela T, Yamamoto M, Anisimov A, Holopainen T, Kaijalainen S, Karpanen T, Lehti K, Yla-Herttuala S, Alitalo K. 2011. Notch restricts lymphatic vessel sprouting induced by vascular endothelial growth factor. Blood 118: 1154-1162.

Zhuo W, Jia L, Song N, Lu XA, Ding Y, Wang X, Song X, Fu Y, Luo Y. 2012. The CXCL12-CXCR4 chemokine pathway: a novel axis regulates lymphangiogenesis. Clin Cancer Res 18: 5387-5398.

Zumsteg A, Christofori G. 2012. Myeloid cells and lymphangiogenesis. Cold Spring Harb Perspect Med 2: a006494.

Zumsteg A, Baeriswyl V, Imaizumi N, Schwendener R, Ruegg C, Christofori G. 2009. Myeloid cells contribute to tumor lymphangiogenesis. PLoS One 4: e7067. 


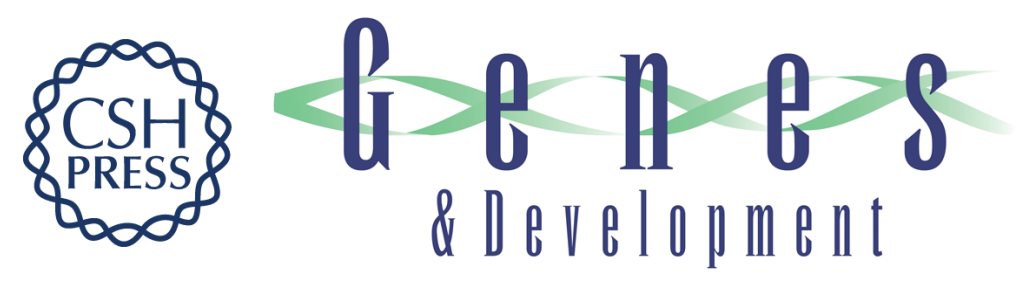

\section{Lymphangiogenesis guidance by paracrine and pericellular factors}

Kari Vaahtomeri, Sinem Karaman, Taija Mäkinen, et al.

Genes Dev. 2017, 31:

Access the most recent version at doi:10.1101/gad.303776.117

References This article cites 275 articles, 123 of which can be accessed free at: http://genesdev.cshlp.org/content/31/16/1615.full.html\#ref-list-1

Creative This article is distributed exclusively by Cold Spring Harbor Laboratory Press for the first Commons six months after the full-issue publication date (see License http://genesdev.cshlp.org/site/misc/terms.xhtml). After six months, it is available under a Creative Commons License (Attribution-NonCommercial 4.0 International), as described at http://creativecommons.org/licenses/by-nc/4.0/.

Email Alerting Receive free email alerts when new articles cite this article - sign up in the box at the top Service right corner of the article or click here.

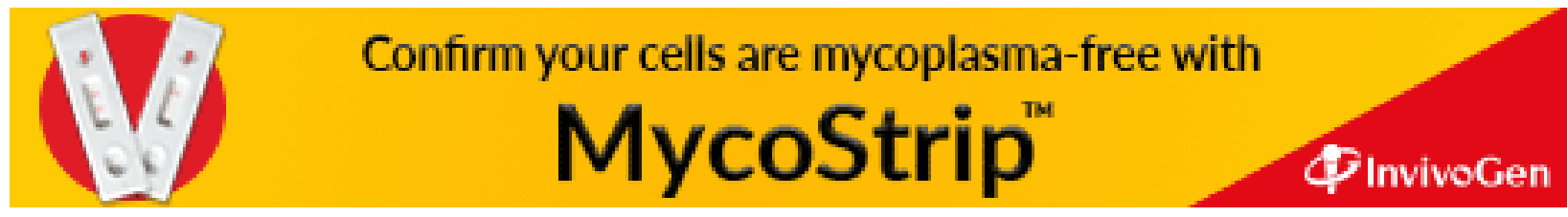

